\title{
Demonstration of the DOE Interim Energy Conservation Standards for New Federal Residential Buildings: Executive Summary
}
A. D. Lee
M. C. Baechler
F. V. Di Massa
R. G. Lucas
D. L. Shankle

January 1992

Prepared for the U.S. Department of Energy under Contract DE-AC06-76RLO 1830

Pacific Northwest Laboratory

Operated for the U.S. Department of Energy

by Battelle Memorial Institute 


\title{
DISCLAIMER
}

This report was prepared as an account of work sponsored b/ an agency of the United States Government. Neither the United States Gover nment nor any agency thereof, nor Battelle Memorial Institute, nor any of their employees, makes any warranty, expressed or implied, or assumes any legal liability or responsibility for the accuracy, completeness, or usefulness of any information, apparatus, product, or process disclosed. or represents that its use would not infringe privately owned rights. Reference herein to any specific commercial product, process, or service by trade name, trademark, mánutacturer, or otherwise does not necessarily constitute or imply its endorsement, recommendation, or favoring by the United States Government or any agency thereof, or Battelle Memorial Institute. The views and opinions of authors expressed herein do not necessarily state or reflect those of the United States Government or any agency thereof.

\author{
PACIFIC NORTHWEST LABORATORY \\ operated by \\ BATTELLE MEMORIAL INSTITUTE \\ for the \\ UNITED STATES DEPARTMENT OF ENERGY \\ under Contract DE-ACO6-76RLO 1830
}

Printed in the United States of America

Available to DOE and DOE contractors from the

Ofice of Scientific and Technical Iniurmation, P.O. Box 62, Oak Ridge, IN 37831; prices available from (615) 576-8401. FTS 626-8401.

Available to the public from the National Technical Information Service, U.S. Department of Commerce, 5285 Port Royal Rd., Springfield, VA 22161. 
DEMONSTRATION OF THE DOE INTERIM ENERGY CONSERVATION STANDARDS FOR NEW FEDERAL RESIDENTIAL BUILDINGS: EXECUTIVE SUMMARY
A. D. Lee
M. C. Baechler
F. V. Di Massa
R. G. Lucas
D. L. Shankle

January 1992

Prepared for the U.S. Department of Energy under Contract DE-AC06-76RLO 1830

Pacific Northwest Laboratory

Richland, Washington 


\section{SUMMARY}

In accordance with federal legislation, the U.S. Department of Energy (DOE) has conducted a project to demonstrate use of its Interim Energy Conservation Standards for New Federal Residential Buildings. The demonstration is the second step in a three-step process: development of interim standards, demonstration of the interim standards, and development of final standards. Pacific Northwest Laboratory (PNL) collected information from the demonstration project and prepared this report under a contract with DOE ${ }^{(a)}$

The purpose of the standards is to improve the energy efficiency of federal housing and increase the use of nondepletable energy sources. In accordance with the legislation, the standards were to be performance-based rather than prescribing specific energy conservation measures. The standards use a computer software program called COSTSAFR which individualizes the standards based on climate, housing type, and fuel costs. The standards generate minimum energy-eficiency requirements by applying the life-cycle cost methodology developed for federal projects.

For the demonstration, the DOE chose five federal agency housing projects: four military housing projects and one project for the Department of Health and Human Services. DOE and PNL worked with agency housing procurement officials and designers/architects to hypothetlcally apply the interim standards to each housing project. PNL conducted extensive intervews with the federal agencies and design contractors to determine what impacts the standards would have on the existing agency procurement process as well as on designers.

Overall, PNL found that the interim standards met the basic intent of the low. Specific actions were identified, however, that DOE could take to improve the standards and encourage the agencies to implement them.

Agency personnel and designers expressed similar concerns about the standards: the minimum efficiency levels established by the standards were lower than expected and the standards did not provide on easy way to incorporate new energy-efficient and renewable resource technologies like solar henting systems.

Agency personnel said the standards would fit into current procurement procedures with no big changes or cost increases. Many said the standards would decrease the time and effort they now spend to establish energy-efnciency requirements and to confirm that propased designs comply with those requirements. Agency personnel praised the software and documentation for being easy to use and providing energy-efriciency requirements in energy dollars. Housing designers agreed that the DOE standards were easy to use to determine that their designs meet energy-eficiency goals. Many felt the information provided by the standards could be useful in the design process.

Based on the demonstration, PNL recommends establishing task forces that will actively involve agency personnel and others in future revisions and development of the final standards. PNL also recommends that DOE and federal agencies investigate the use of market fuel and energy prices in the standards, rather than the prices paid by the agencies, to better reflect actual costs. A number of recommendations are made for improving communications between DOE and the users of the standards and for enhancing tools to implement the standards. Several recommendalions are made for increasing

(B) Pacific Northwest Laboratory is operated by Battelle Memorial Inslitute for the U.S. Department of Energy under Contract DE-ACO6-76RLO 1830. 
the number of renewable resources that are included in the standards. Finally, PNL recommends ongoing monitoring activities to continue to identify ways in which the standards can be improved. 


\section{CONTENTS}

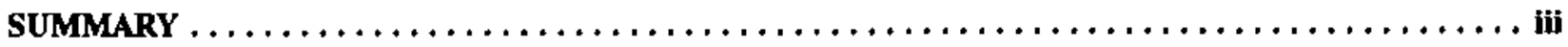

1.0 INTRODUCTION AND OVERVIEW $\ldots \ldots \ldots \ldots \ldots \ldots \ldots \ldots \ldots \ldots \ldots \ldots \ldots \ldots \ldots \ldots \ldots \ldots$

2.0 DESCRIPTION OF STANDARDS $\ldots \ldots \ldots \ldots \ldots \ldots \ldots \ldots \ldots \ldots \ldots \ldots \ldots \ldots \ldots \ldots \ldots, \quad 2.1$

2.1 SOFTWARE DESCRIPTION AND USE $\ldots \ldots \ldots \ldots \ldots \ldots \ldots \ldots \ldots \ldots \ldots \ldots, 2.1$

2.2 ALTERNATIVE COMPLIANCE PROCEDURE $\ldots \ldots \ldots \ldots \ldots \ldots \ldots \ldots \ldots \ldots, 2.4$

2.3 ANTICIPATED ROLE OF STANDARDS IN FEDERAL AGENCY PROCUREMENTS . . 2.4

3.0 ANALYSIS APPROACH $\ldots \ldots \ldots \ldots \ldots \ldots \ldots \ldots \ldots \ldots \ldots \ldots \ldots \ldots \ldots \ldots \ldots \ldots \ldots \ldots \ldots \ldots \ldots, 1$

3.1 GOALS OF THE INTERIM RESIDENTIAL STANDARDS $\ldots \ldots \ldots \ldots \ldots \ldots \ldots \ldots \ldots, 3.1$

3.2 OBJECTIVES OF THE STANDARDS $\ldots \ldots \ldots \ldots \ldots \ldots \ldots \ldots \ldots \ldots \ldots \ldots \ldots \ldots .1$

3.3 MEASURING ACHIEVEMENT OF THE OBJECTIVES $\ldots \ldots \ldots \ldots \ldots \ldots \ldots \ldots \ldots, 3.2$

3.4 INTEGRATION OF THE RESULTS $\ldots \ldots \ldots \ldots \ldots \ldots \ldots \ldots \ldots \ldots \ldots \ldots \ldots \ldots, \ldots \ldots$

3.5 DEVELOPMENT OF RECOMMENDATIONS $\ldots \ldots \ldots \ldots \ldots \ldots \ldots \ldots \ldots \ldots \ldots, 3.4$

4.0 DEMONSTRATION PROJECT CASE STUDIES $\ldots \ldots \ldots \ldots \ldots \ldots \ldots \ldots \ldots \ldots \ldots \ldots \ldots$

4.1 AIR FORCE CASE STUDY $\ldots \ldots \ldots \ldots \ldots \ldots \ldots \ldots \ldots \ldots \ldots \ldots \ldots \ldots \ldots \ldots \ldots \ldots$

4.2 FORT POLK CASE STUDY $\ldots \ldots \ldots \ldots \ldots \ldots \ldots \ldots \ldots \ldots \ldots \ldots \ldots \ldots \ldots \ldots .3$

4.3 FORT IRWIN CASE STUDY $\ldots \ldots \ldots \ldots \ldots \ldots \ldots \ldots \ldots \ldots \ldots \ldots \ldots \ldots \ldots \ldots$

4.4 NAVY CASE STUDY $\ldots \ldots \ldots \ldots \ldots \ldots \ldots \ldots \ldots \ldots \ldots \ldots \ldots \ldots \ldots \ldots \ldots \ldots \ldots$

4.5 PUBLIC HEALTH SERVICE CASE STUDY $\ldots \ldots \ldots \ldots \ldots \ldots \ldots \ldots \ldots \ldots \ldots \ldots \ldots .8$

5.0 DEMONSTRATION PROJECT FINDINGS AND DISCUSSION $\ldots \ldots \ldots \ldots \ldots \ldots \ldots \ldots \ldots$.

5.1 PRESENTATION OF FINDINGS $\ldots \ldots \ldots \ldots \ldots \ldots \ldots \ldots \ldots \ldots \ldots \ldots \ldots \ldots \ldots, 5.1$

5.2 IMPACTS ON ENERGY EFFICIENCY AND USE OF RENEWABLE RESOURCES $\ldots \ldots .5 .1$ 
5.3 IMPACTS OF THE U.S. DEPARTMENT OF ENERGY STANDARDS ON FEDERAL AGENCIES

5.4 IMPACTS OF THE U.S. DEPARTMENT OF ENERGY STANDARDS ON DESIGNERS AND BUILDERS $\ldots \ldots \ldots \ldots \ldots \ldots \ldots \ldots \ldots \ldots \ldots \ldots \ldots \ldots \ldots \ldots \ldots \ldots$

5.5 U.S. DEPARTMENT OF ENERGY ROLE IN IMPLEMENTING THE STANDARDS $\ldots \ldots .11$

6.0 RECOMMENDATIONS $\ldots \ldots \ldots \ldots \ldots \ldots \ldots \ldots \ldots \ldots \ldots \ldots \ldots \ldots \ldots \ldots \ldots \ldots, \ldots \ldots \ldots$

6.1 INCREASING THE EFFECTIVENESS OF PARTICIPATION IN THE DEVELOPMENT AND IMPLEMENTATION OF U.S. DEPARTMENT OF ENERGY STANDARDS $\ldots \ldots \ldots$. 6.1

6.2 IMPROVING PROCEDURES AND PROCESSES $\ldots \ldots \ldots \ldots \ldots \ldots \ldots \ldots \ldots \ldots \ldots \ldots .2$

6.3 REVISING INTERIM STANDARDS AND DEVELOPING FINAL STANDARDS $\ldots \ldots \ldots .3$

6.4 ACCOMMODATING RENEWABLE RESOURCES AND NEW ENERGY-EFFICIENT TECHNOLOGIES $\ldots \ldots \ldots \ldots \ldots \ldots \ldots \ldots \ldots \ldots \ldots \ldots \ldots \ldots \ldots \ldots . \ldots \ldots$

6.5 MONITORING IMPLEMENTATION AND IMPACTS OF THE STANDARDS $\ldots \ldots \ldots \ldots .5$

6.6 Conclusions $\ldots \ldots \ldots \ldots \ldots \ldots \ldots \ldots \ldots \ldots \ldots \ldots \ldots \ldots \ldots \ldots \ldots \ldots \ldots$

7.0 REFERENCES $\ldots \ldots \ldots \ldots \ldots \ldots \ldots \ldots \ldots \ldots \ldots \ldots \ldots \ldots \ldots \ldots \ldots \ldots \ldots \ldots \ldots \ldots, \ldots \ldots .1$ 


\section{FIGURES}

2.1. Sample Sections of a Point System Compliance Form

\section{TABLES}

1.1. Climate Regions

1.3

3.1. Measurement of Objectives

5.1. Actual Federal Housing Fuel Prices

5.2. Comparison of Five Case-Study Minimum-Points Redesigns

Showing Life-Cycle Costs and Savngs per Unit 


\subsection{INTRODUCTION AND OVERVIEW}

This report describes a project conducted to demonstrate the U.S. Department of Energy's (DOE's) Interim Energy Conservation Standards for New Federal Residentlal Buildings. DOE was assisted in the demonstration project by Pacific Northwest Laboratory (PNL). ${ }^{(a)}$ A much more detalled version of this report is also available. ${ }^{(b)}$

DOE developed the Interim Energy Conservation Standards in response to a series of laws. Public Law 94-385, the Energy Conservation Standards for New Buildings Act of 1976 (42 U.S. Code (USC) 6831. 6840, as amended), established the initial requirements for the development and implementation of performance standards for new residential buildings. The standards were to be "designed to achieve the maxdmum practicable improvements in energy efficiency and increases in the use of nondepletable sources of energy. ..." (42 USC 6831). The original act did not distinguish between standards for federal and private-sector buildings, and did not require a demonstration project. ${ }^{(c)}$

A 1980 amendment to the act, Public Law 96-399 (42 USC 6833), required DOE to conduct a threestep process that included promulgating interim standards, conducting a demonstration project, and developing and promulgating final standards. Specifically DOE was required to

develop and publish in the Federal Repister ... standards for new residential buildings ... and, for at least the 12-month period [after promulgation] . . . conduct a demonstration project utilizing such standards in at least two geographical areas in different climatic regions of the country ... [N] later than 180 days after completing such demonstration project, such Secretary of Energy shall transmit to both Houses of the Congress a report containing an analysis of the findings and conclusions made as a result of carrying out such a project including at least (A) an analysis of the impacts of sucb standards on builders (especially on small builders) and on the cost of constructing such bulldings and the impact of such cost on the ablity of low- and moderate-income persons to purchase or rent such buildings, and (B) an analysis of the estimated total energy savings (including the types of energy) to be realized from utilizing such standards in residential bulldings. Final ... performance standards for such buildings shall be promaigated . . (42 USC 6833(a)(2)).

It is important to note that the original legislation and the amendments throngh 1980 were designed primarily to be applied to private-sector buildings receiving federal financial nssistance. Thus, the requirements regarding the three-stage process and a demonstration project were driven largely by the characteristics of the private-sector housing market rather than the characteristics of federal housing.

In 1981, Public Law 97-35 modified the requirements to make the standards voluntary for the private sector. They continued, however, to be mandatory for the federal sector. In response to this amendment, DOE separated its residential interim standards development and demonstration efiorts into

(a) Pacific Northwest Laboratory is operated by Battelle Memorial Institute for the U.S. Department of Energy.

(b) Lee, A. D, M. C. Baechler, F. V. Di Massa, R. G. Lucas, and D. L. Shankle. 1991. Demonstration of the DOE Interim Energy Conservation Standards for New Federal Residential Buildings. PNL7956, Pacific Northwest Laboratory, Richland, Washington.

(c) Federal huildings were defined as "any building to be constructed by, or for the use of, any Federal agency which is not legally subject to State or local building codes or similar requirements" (Energy Conservation Standards for New Buildings Act of 1976, Sec. 303). 
one standard for voluntary private-sector standards and another for mandatory federal residential standards.

In accordance with the legislation, DOE developed the interim standards, which are software-based. An advisory group comprised of representatives of the military serves reviewed the software during development of the standards and provided comments and suggestions on solware design. (a) The energyeficiency performance-based requirements of the standards are specific to each housing project, taking into account local climate and fuel costs.

On August 25, 1988, DOE published the interim standards, and they tecame effective for federaI agencies on February 21, 1989 (53 Federal Register (FR) 32536-46). ${ }^{\text {(b) }}$ On the same day, DOE published for comment a proposed modification that added credit for three difierent thermal mass wall configurations, added new data and options for energy-eficient windows, and established an alternate compliance procedure (53 FR 32547-55). On January 31, 1991, the modified interim standards were published and became effective on July 30, 1991 (56 FR 3765-3773). Although federal agencies provided some comments on the standards, there was little evidence that agencies began implementing the interim standards when they became effective.

The legislation required DOE to conduct a demonstration of the standards and to prepare a report to Congress containing an analysis of the findings and conclusions. This document and its companion volume comprise that report. The information reported here from the demonstration will be used as the basis for developing final standards.

The demonstration consisted of hypothetical applications of the interim standards to five federal agency housing projects. The projects were actual bujldings, already designed or constructed in tive diverse geographic and climatic zones. The legislation required that the demonstration be conducted in at least two geographical areas in different climatic regions of the country. Because climate and utility prices are the main driving forces in the requirements established by the standards, DOE decided to select housing projects in five different climate regions rather than the minimum of two reglons required. Expension to five regions increased the diversity represented by the demonstration results. The five regions were based on the climate characteristics shown in Table 1.1.

Federal agencies were requested to use the standards retroactively to generate energy-eficiency requirements for the projects, which had been designed based on existing agency requirements. PNL then subcontracted with design firms to determine what changes they would have made to the original design to meet the requirements of the DOE standards. The demonstration was a "paper" study; no actual design or construction work was undertaken.

The legislation required the demonstration to be conducted for at least 12 months after promulgation of the interim standards. The interim standards became effective on February 21, 1989, and the demonstration commenced on this date. ${ }^{(c)}$ The report to Congress had to be delivered within 180 days

(a) It was determined eariy in the development phase that over $90 \%$ of housing to which the standards would apply is built by or for the military.

(b) The actual language of the standards can also be found in 10 Code of Federal Regulations (CFR) Part 435.

(c) These modified interim standards (issued for comment on August 25, 1988 and effective on July 31, 1991) were used in the demonstration because 1) they added flexibility to the original interim standards and 2) they made the results of the demonstration relevant to the very latest version of the interim standards. 
TABLE 1.1. Climate Regions

\section{Climate Region}

Hot

Hot and humid

Mild

Cold

Very cold
Description (a)

Greater than 2000 cooling

degree-days ${ }^{(b)}$

Greater than 2000 cooling degree-days and relative humidity greater than $\mathbf{7 5 \%}$

2000 to 5000 heating degree-days

5000 to 7500 heating degree-days

Greater than 7500 healing

degree-days

(a) Units are heating or cooling degree-days per year besed on an ambient temperature of 65 degrees $F$.

(b) The number of degree-days for one day is the difference between the base temperature and the mean daily ambient temperature. Degree-days per year are the sum of the daily degree-days for all of the days of the year.

aner the demonstration was completed. The demonstration was completed on September 2, 1991, and the report to Congress will be delivered within 180 days of that date.

As part of the demonstration, extensive interviews were conducted to document current agency and designer practices. Data collection forms were developed and used to document the likely effects of the standards. Current agency and designer practices established a baseline from which the incremental impacts of the DOE standards were measured. Impacts that were analyzed included both qualitative and quantitative effects, specifically effects on agency and designer processes, housing costs, and energy consumption.

Chapter 2 of this report describes the standards and the process for implementing them. Chapter 3 discusses the demonstration analysis methodology. Four federal agencies participated in the demonstration: the Air Force, the Army (which provided two case studies), the Navy, and the Department of Health and Human Services. The agency case studies are described in Chapter 4. Chapter 5 presents the overall findings from the demonstration projects. Chapter 6 presents the recommendations based on this demonstration and Chapter 7 lists the references. 



\subsection{DESCRIPTION OF STANDARDS}

Congress required DOE to develop performance-based energy-eficiency standards for housing. Performance-based standards require houses to perform to certain levels of energy eficiency, rather than requiring that specific measures or devices be installed. To be consistent with the performance-based requirement and to produce the maximum practicahle improvements in energy eficlency, DOE and PNL developed energy conservation standards that set requirements which are based on project-specific conditions, such as local climate, types of houses, applicable fuel prices, and local construction costs, rather than being pre-delined.

Early in the development process it became clear that a sofware tool would be needed to calculate housing performance using site-specific criterln. Initlal development of the software started in 1984. The sottware is called the Conservatjon Optimization Standard for Savings in Federal Residences

(COSTSAFR). COSTSAFR is designed to be implemented by federal oficials responsible for federal housing procurement.

\subsection{SOFTWARE DESCRIPTION AND USE}

The COSTSAFR software operates on IBM personal computers or other IBM-compatible personal computers. COSTSAFR is designed to be used by federal housing procurement offcials. Its primary purpose is to produce point system compliance forms, which are discussed later. Each form provides a list of the most cost-effective energy conservation choices for a number of building components in one type of residential building. The form also gives the user a point total representing a minimum reduction in energy costs that must be achieved. This reduction is the target that any building design must meet to comply with the standards. COSTSAFR is intended to be simple to operate, requiring the user to enter only basic information relating to a federal housing construction project. A user's manual provides the information needed to operate COSTSAFR (DOE 1983a).

The COSTSAFR program does a project-specific bfe-cycle cost (LCC) aualysis using a 25-year period of analysis and a federal discount rate established by the Federal Energy Management Program (FEMP). Fuel price escalation rates for future years are established and updated yearly by FEMP. The LCC analysis accounts for tradeofls between the non-energy costs (purchase, maintenance, replacement costs, and salvage values) of energy conservation measures (ECMs), and the ECM life-cycle energy cost savings over the life of a house. For a given run, the LCC analysis produces an "optimum design," which is the set of ECMs with the lowest LCC, based on the ECMs included in COSTSAFR. The total energy cost savings for the optlmum design establish a point total. This point total represents the target energy cost reduction one must meet to comply with the standards. Technical support documents provide detailed information about the economic and technical underpinnings of the standards and the software (DOE 1988b, DOE 1988c).

Agency officials enter data that include the year of occupancy, project locntion, allowable foundntion and housing types, allowable space heating fuel and equipment types, whether air-conditioning is included, ellowable domestic hot water (DHW) equipment types, and fuel costs. COSTSAFR analyzes seven different prototypical houses: single- and double-section manufactured houses; ranch, two-story, and split-level detached houses; and town house and apartment low-rise attached housing." (n)

(a) COSTSAFR analyzes both mid- and end-units in town houses and low-rise attached housing, and generates separate compliance forms for the mid- and end-units, if desired. Consequently there are nine different unit types that can be analyzed. 
The ECMs incorporated in COSTSAFR include envelope component (ceiling, wall, and Aoor) insulation levels; window types; heating and cooling equipment types and eficiencies; and refrigerator/freezer and water heater types and eficiciencies. In performing the LCC analysis, COSTSAFR accesses two databases containing ECM data.

One database contains all ECM cost data, including initial cost, maintenance cost, replacement costs, and salvage values. COSTSAFR allows the user either to make overall adjustments to the ECM cost database to account for inflation and local construction costs, or to change individual ECM costs. The second database contains the ECM energy consumption data. The energy databese was created with the DOE-2.1 (DOE 1988c) building simulation model.

Three versions of COSTSAFR have been issued to the public to date. Version 1 was issued in the Federal Register for public comment on August 20, 1986 (51 FR 29754). The COSTSAFR program was modified in 1987 in response to the public comments and also to make general improvements and updates. On August 25, 1988, Version 2 was issued ( 53 FR 32536). Version 3 was issued on the same date for public comment ( $53 \mathrm{FR} 32547$ ). These new versions were very similar in appearance and operation to the original version. Version 2 is the Final Interm Rule, which became effective on February $21,1989$. Version 3 is similar but has new, improved window energy data and has the additional ECM category of walls with thermal mass (i.e., heavyweight materfals to take advantage of solar energy). Version 3 was further improved to become Version 3.1, which became available in late 1991.

The energy-efinciency requirements of the standards are presented in point system compliance forms produced by COSTSAFR. The paper version of these compliance forms is about seven pages long. Each form is customized so that the energy-efficlency requirements stated on the form are based on the location, fuel costs, and building type of the particular project. The point system compliance forms are used by designers (usually prospective housing contractors) to develop a design that complies with the DOE standards.

COSTSAFR calculates points for all ECMs included in the database. COSTSAFR determines points for a specific ECM by comparing its life-cycle energy cost savings with those of the least energy-eficient ECM in the COSTSAFR database for that component. For example, the least efficient ECM for ceilings is R-11 insulation so the points for R-19 ceiling insulation are related to the life-cycle energy cost savings that R-19 provides when compared with R-11. The set of ECMs that produces the lowest life-cycie cost (including first cost, energy cost, and all other costs) constitute the optimum design choices. The point total for the optimum design establishes the target that buildings must meet.

The designer uses the point system to evaluate selected ECMs for each component in a house design. The point system tells the designer how many points each selected ECM is worth. To show compliance, the designer's point total must meet or exceed the target determined by COSTSAFR.

The designer must make an ECM selection for each of the following components: ceiling, wall, and noor insulation; infitration controls; window types and areas; space heating and cooling equipment and eficiencies; water heater type and efticiency; and refigerator/freezer efficlency (if desired by the federal agency). The designer also may select wndow coatings or treatments (e.g, low-emissivity glazing), sun spaces, movable window insulation, and roof color to improve energy efilciency.

Fgure 2.1 shows sample sections of the point system. The ceiling and wood freme wall sectlons of the point system are shown for a split-level house in Denver, Colorado. The numbers in the heating and cooling columns are the COSTSAFR-generated, project-specific polnts. The optimized selections are shown beneath each list of options. 


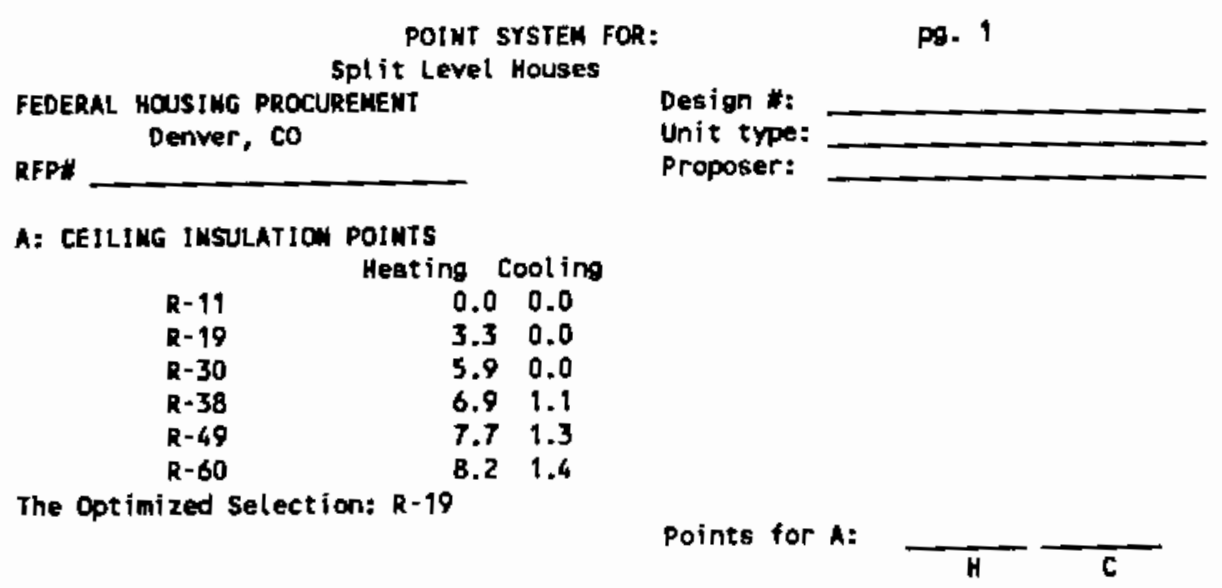

B: WALL INSULATION POINTS (Select either Hood frame or Thermel Mass Halls)

Wood Frane Walls

$\begin{array}{llc}R-11 & H & C \\ R-13 & 0.0 & 0.0 \\ R-19 & 1.3 & 0.0 \\ R=24 & 5.2 & 0.0 \\ R-26 & 7.3 & 0.0 \\ R & 8.0 & 0.0\end{array}$

The optinized Selection: R-19

Points for B:

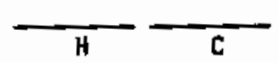

FIGURE 2.1. Sample Sections of a Point System Compliance Form

The requirement of mexting a minimum point total ensures that a cost-effective level of energy conservation is met or exceeded. The points assigned to individual options in the point system represent energy cost savings and do not include non-energy costs.

The point system can be completed on paper or by using a computer program called CAPS (Computerized Automated Point System). Either format can be used to specify a set of ECMs that complies with the standards Ior any given project.

The CAPS software allows the user to input design selections into a personal computer. The CAPS program automatically does all the calculations necessary to determine the point total obtained for the user-selected ECMs, eliminating the possibility of math errors. Furthermore, CAPS instantiy calculates the point total when the user selects an ECM and notifies the user whether the design complies with the standards. This software provides the user with immediate feedback on the impact of any ECM selection. ${ }^{(\bullet)}$

(a) At the time the demonstration project was conducted, use of a program called POSTSAFR was necessary to prepare COSTSAFR point system files for CAPS. A number of negative comments were received from federal oficials about the extra inconvenience that use of the POSTSAFR program necessitated. PNL updated the COSTSAFR and CAPS software issued in 1991 to completely eliminate the need for POSTSAFR. 


\subsection{AUTERNATIVE COMPLIANCE PROCEDURE}

The typical method for complying with the interim standards is for the federal agency to use COSTSAFR to generate the point systems the designer uses to demonstrate compliance. Although the COSTSAFR program covers a wide range of ECMs, it does not have the ability to analyze all building designs and unusual or innovative ECMs. Therefore, an alternate means of compliance for such designs, the alternative compliance procedure (ACP), is provided. The ACP permits analysis of designs, materlals, and construction techniques not covered by COSTSAFR, and remains consistent with the basic framework and economic assumptions of COSTSAFR. The ACP should be used if the designer for a new federal housing project proposes energy conservation design features not inciuded in COSTSAFR.

To be consistent with the energy database used by COSTSAFR, the ACP requires use of the DOE-2.1 simulation model (DOE 1988c) to calculate the yearly space conditioning energy loads (energy consumption for henting and cooling) for the proposed house. The yearly loads are adjusted by equipment eficiency and fuel escalation rates to obtain the 25-year LCC for energy. To comply with the interim standards, the life-cycle energy costs calculated based on DOE-2.1 nuns of the proposed design must be equal to or less than the energy costs for the optimum design calculated by COSTSAFR for the COSTSAFR prototype most similar to the proposed design.

\subsection{ANTICIPATED ROLE OF STANDARDS IN FEDERAL AGENCY PROCUREMENTS}

Federal agencies use several processes to procure new housing. Typically, a private contractor is hired to design the housing units. Many agencies use a "turnkey" process in which they conduct a competitive Request for Proposal (RFP) process, and the winning contractor both designs and builds the units. Some agencies separate the design and bullding phases by first awarding a contract for the design only, and then hiring a construction contractor to build the units.

For most procurement processes, the use of the standards will be a three-part process: 1) generation of the point system by the federal agency using COSTSAFR and integration of the point system compliance form with the RFP package, 2) completion of the point system by the designer, and 3) agency evaluation of the proposed designs and verification that the designs comply with the standards. Use of the COSTSAFR software and use of the point system are separate processes: the designer using the point system never needs to use COSTSAFR. The point system was designed to be simple enough to use that it does not cause the designer any signifleant dimculties or delays.

The federal agency will use the COSTSAFR software to generate point system compliance forms. The point system and the associated instructions will be included with the RFP packnge sent to interested parties. The design architects and engineers (A\&Es) show compliance with the standards by completing the point system form and specifying a set of ECMs that meets the required point total. Evaluation of the completed point system will be part of the agency's overall technical evaination of proposals. 


\subsection{ANALYSIS APPROACH}

The intent of the demonstration was to determine the effects of the standards and develop indings and conclusions that could be used as the basis for the development of nnal standards. To fulfill this intent, the information and data collected during the demonstration were analyzed to evaluate how well the standards were able to achieve the goals and ohjectives they needed to meet to be successful.

The analytic approach used was a "goal-oriented" program evaluation (Stecher and Davis 1987). In such evaluations, program performance is measured in terms of the set of goals and objectives defined for the program. This approach requires delining the program goals and then establishing objectives against which the success of the program can be measured.

\subsection{GOALS OF THE INTERIM RESIDENTIAL STANDARDS}

Three goals were established for the federal residentlal standards program. These were to

- achieve maximum practicable energy-eficiency improvements

- increase the use of renewable resources

- facilitate successful implementation of the standards by federal agencies, designers/builders, and DOE.

The first two goals were mandated by federal law, as discussed earlier. The third goal was essential to ensure that the standards accomplished wbat they were designed to do.

\subsection{OBJECTIVES OF THE STANDARDS}

Establishing the standards' objectives was necessary to permit the evaluation and assessment of the standards. The objectives helped to shape data collection and analysis, and they provided a means by which to measure the performance of the interim standards. A comprehensive list of 19 objectives necessary to meet the goals was developed. The objectives were then rank-ordered by importance. Many of the objectives were considered to be of about equal importance. The 12 most important objectives were as follows:

- generate maximum practicable energy-eficiency requirements (1)

- encourage use of renewable energy resources (1)

- accommodate existing renewable resource technologies (2)

- build consensus among user agencies (2)

- minimize disruption to agency processes and simplify use of the standards (2)

- provide training/support to agencies (2)

- minimize disruption, cost impacts, and complications to design/construction processes (2)

- provide training/support to designers/builders (2)

- facilitate periodic reviews/updates by DOE (3)

- achieve compliance in houses built under requirements of the standards (4) 
- permit incorporation of new energy-efriciency technologies (4)

- [acilitate distribution of appropriate standards materials to appropriate people at agencies (4).

The numbers following the objectives listed above indicate their importance in the ranking. This ranking was used to focos the analysis of the data and information from the demonstration. ${ }^{(a)}$

The first three objectives ordginated in the Congressional purpose for the standards. The five remaining second-level objectives were associated wth implementation of the standards by federal agencies and housing designers. If DOE could use the standards to "build user agency consensus" on the importance of energy eficiency and the approach used to incorporate it in federal housing then energy efficiency would be more viable over the long term and costs of implementing it would decline. A key element of implementation would be providing adequate training to both agencies and designers/builders.

DOE believed that agencies and designers/builders would be more receptive to the standards if the standarts could be updated as conditions and information changed. Thus, it was essential to ascertain how feasible it was to update the standards. The effectiveness of the standards would depend not only on the eficiency levels established but also on verification that designers and builders were complying with them. Therefore, assessment of compliance with the standards became a key objective. The effectiveness of the standards also would depend on how adequately the necessary materials were distributed to both agency personnel and designers/builders.

\subsection{MEASURING ACHIEVEMENT OF THE OBJECTTVES}

The methodologies selected to measure achievement of the 12 objectives are listed in Table 3.1. Many of the measurements were based on qualitative information collected throngh the interviews with agency or designer personnel.

Some of the objectives were unlikely to be achieved by the standards because of decisions made during the development phase. For example, DOE had decided that renewable energy technologies and new energy-efificiency technologies should be included in the standards only if valid testing procedures existed. This requirement was intended to prevent risky or unproven technologies from receiving undue credit in the standards. Consequently, it was known at the outset that objectives 2 ("Encourage use of renewable energy resources") and 11 ("Permit incorporation of new energy-eficiency technologies") would not be fully met. Nevertheless, measuring how well these objectives were achieved by the interim standards would help DOE determine their importance during development of the final standards.

Several of the objectives were related to the process of implementing the standards, rather than the requirements of the standards themselves. For example, objective 12, "Provide materials to appropriate agency personnel," is a procedural objective that may require actions by DOE and the headquarters and field office staft of implementing agencies. Measuring how well such objectives were achieved provided insights into where problems might arise and ways to alleviate them.

(a) The other seven objectives, which were considered less important, were as follows: incorporate mechanisms to provide designer/bullder feedback, accommodate new renewable resource technologies, elicit public comment and involvement, faclitate distribution of appropriate standards materials to designer and builder personnel, provide tracking and monitoring of the standards for DOE, incorporate mechanisms to provide agency feedback, and minimize negative economic impacts on housing occupants. 


\section{TABLE 3.1. Measurement of Objectives}

\section{Objectives}

\section{Generate maxdinum} practicable energy-fificiency requirements

2. Encourage use of renewable energy resources

3. Accommodate exdsting renewable resource technologies

\section{Build consensus among user agencies}

5. Minimize disraption to agency processes and simplify use of the standards

\section{Provide training/support to} agencies

7. Minimize disruption, cost impacts, and complications to design/construction processes

8. Provide training support to designers/builders

9. Facilitate periodic reviews/updates by DOE

10. Achieve compliance in houses built under the standards

11. Permit incorporation of new energy-efficiency technologies

12. Provide materials to appropriate agency personnel
Methodologies to Measure Achievement

Detine "maximum practicahle;" compare requirements of standards with agency current practice and other codes; examine technical feasibllity of high-efficiency requirements.

Determine whether agencies and designers believe standards encourage use of renewables.

Determine whether agencies and designers feel standards accommodate existing renewables and demonstration redesigns include renewables.

Assess whether agencies agree on the value of the standards and the benefits of a uniform approach across agencies.

Determine whether standards are easy for agencies to implement, cause minimum disruptions or complications, and simplify current agency processes.

Assess whether DOE assistance has made it easy lor agencies to use standards and minimizes problems.

Determine whether the standards impose few problems and minimum costs on designers and builders.

Assess whether DOE assistance has made it easy for designers to use standards and minimizes problems.

Determine whether standards' software and process aljow easy updates. Determine whether DOE has an effective review/update process in place.

Verify that housing built under the standards has the required measures installed and performs as predicted.

Determine whether the standards have the flexibility to include new technologies.

Assess whether agency procurement oficials have received all the materials needed to implement the standards effectively. 


\subsection{INTEGRATION OF THE RESULTS}

Each of the projects in the demonstration was treated as a case study and evaluated as to how well the standards performed according to each of the goals and the objectives listed in Table 3.1. To determine how well the interim standards achieved their goals, the results from the case studies were reviewed for common themes and trends. The summary of these findings is presented in Chapter 4 of this report.

\subsection{DEVELOPMENT OF RECOMMENDATIONS}

Based on the overall findings, a set of recommendations was developed on what should be done to improve the effectiveness of the standards. The analysis of the findings from the interviews with agency staff and designers provided the impetus for many of the recommendations that are offered in Chapter 5 of this report. These recommendations are presented as the basis for DOE's development of the final standards. 


\subsection{DEMONSTRATION PROJECT CASE STUDIES}

Case studies were conducted to demonstrate impacts of the DOE standards on five actual housing projects located in five climate regions throughout the country. The case studies were conducted wth the participation of various federal agencles who are involved in the procurement of housing for their staff. Case study housing projects for the demonstration were located as follows: 1) Ellsworth Air Force Base, Rapid City, South Dakota - Air Force, 2) Fort Polk, Alexandrta, Louisiana - Army, 3) Fort Irwin, Barstow, California - Army, 4) Alameda Naval Air Station, Alumeda, California - Navy, and 5) Indlan Health Services, Rosebud, South Dakota - Public Health Service.

\subsection{AIR FORCE CASE STUDY}

This project was developed under the auspices of the Strategic Alr Command at the Offutt Air Force Base in Nebraska. The project consisted of 124 split-level houses constructed at the Ellsworth Air Force Base near Rapid City, South Dakota, a location in the "cold" or "very cold" climate zone.

In this and other housing procurements, the Alr Force follows general U.S. Department of Defense procedures. It favors the turnkey procurement process in which one contractor is chosen in response to a request for proposals and this contractor prowides both design and construction services. For each RFP the Air Force sends out it also develops a "Residential Energy and Economic Evaluation Manual" (REEEM). The REEEM inciudes site-specific design guidelines on subjects such as site planning, building envelope design, mechanical equipment, and energy suving combinations. It provides a common method for proposers to evaluate the energy and economic performance of their designs. The RFP typically defines a heating and cooling energy budget and references the REEEM as the method to use to demonstrate compliance. The proposed design must reduce ICC compered with a base-case huilding. The design must also meet an energy consumption target established by the Air Force.

\subsubsection{Agency Impacts}

The DOE standards would affect the Air Force during RFP preparation end proposal evaluation. The DOE standards would eliminate the need to produce a REEEM for each project and would save the Alr Force the associated casts. The DOE standards would also reduce the labor required at the command and base level, possihly three or four person-days.

The DOE standards may shif the task of developing the energy-eficiency requirements from headquarters to the command and base level; however, it appeared that the impacts would be minimal and field office participants were not adverse to using the new technology.

Air Force stafl found COSTSAFR easy to use. They spent about one hour learning how to use the software and four hours generating the point system energy-eficiency requirements.

Several commented that cost date would need to be updated and if the Air Force had to update this information it would be a major effort.

Housing procurement stalf felt that, compared wth the current procedure, the DOE standards would reduce the amount of time evaluators would have to spend on energy-eficiency analysis. Howrever, headquarters staff noted that COSTSAFR needed to do a better job with passive solar. In particular, it did 
not allow the evaluator to determine whether a proposed design met the Air Force's requirements for the solar contribution in meeting the heating load. ${ }^{(\Delta)}$

Although the DOE standards' ACP provldes the flexibility to assess technologies such as solar systems, Alr Force start suggested that using the ACP during evaluation would be time consuming and challenging.

\subsubsection{Designer Impacts}

The designer said little effort was required to learn how to use the paper point system. Larning the point system and filling it out took less than five hours. Leaming to use CAPS took about one-half hour. The DOE procedure should require less effort by the designer than the current Air Force procedure.

The DOE standards would reduce the labor designers must dewote to preparing their proposals, if the $\mathrm{ACP}$ is not required. However, if designers want to use innovative designs and request use of the $\mathrm{ACP}$, the DOE standards might increase costs to both the agency and the designers.

The designer mentioned several interpretation problems: how to treat buildings not aligned with a North-South axis; how to calculate the floor area; and how to handle buildings with an unusual mix of design features, e.g, a building with a slab-on-grade, a crawl space, and a bosement.

The designer was concerned about not being allowed to analyze unusual design features. He noted that several ECMs not currently incorporated in the point system should be included as options; for example, water heater wraps, energy-fincient lighting, low-תow faucet aerators and shower heads, and active solar water heating and space heating systems. He felt most firms would not have the time or expertise to Implement the ACP to analyze innovative measures.

The designer stated that updates should be made to the economic and technical data in the standards to ensure that they are current. He commented that the minimum energy-efficiency levels required by the standards seemed outdated when compared to other standards and current practice.

The COSTSAFR analysis for this project was based on a natural gas price of 20 cents/therm and an electricity price of 7.2 cents/kWh. The low gas price skewed the resulting point system requirements, so that the energy-eficiency levels in the houses redesigned based on the COSTSAFR anglysis were relatively low.

\subsubsection{Redesign of Air Force Units to DOE Standards}

For the split-level houses in the project, the standards required a total of 67 points in the COSTSAFR point system; the actual built design achieved 79.5 points. The A\&E firm was asked to submit two redesigns corresponding to two different ways the designer might have responded to the DOE staudards' requirements.

In the first redesign, the A\&E firm reduced the ECM levels selected in the original design to match the DOE standards' minimum point total requirement of 67 points as closely as possible. Changes made under this modification included the following: 1) using R-19 ceiliug unfaced batt insulation in place of $R$ 38; 2) substituting 2x4-In. wall studs with R-11 batt insulation for 2x6-in. studs with R-19 batt insulation and rigid insulation; 3) decreasing the foor insulation from R-19 to R-11; 4) and substituting doublepane, aluminum frame windows for wood frame windows. Compared with the original design, this redesign

(a) A similar comment was voiced about the dififculties of using the current Air Force approach to evaluate the solar contribution. 
was estumated to decrease capital cost to the Air Force by about $\$ 2,160$ per unit, or about $\$ 260,000$ for the 124 units built. Because the units would be less energy-efficient than the units as built, however, the discounted present value of life-cycle energy costs would have increased about $\$ 814$ per unit, or $\$ 110,000$ for all 124 units. Therefore, the DOE standards would have decreased overall life-cycle costs for each unit $\$ 1,286$, or about $\$ 150,000$ for all 124 units.

The second redesign considered was with each unit designed to meet the original point total of 79.5, but with ECMs selected to minimize the capital cost. CAPS was used to find ways to reduce capital costs without increasing energy use. Compared with the original design, the estimated cost of each unit wonld decrease by about \$615, for a total decrease in capital costs of \$76,000.

In terms of energy consumption, the first approach would have increased energy consumption compared with the original design. The increase for each house would have been about $9 \%$, or 19 million Btu per year. Consumption of natural gas would have increased by 18.6 million Btu per year and electrtcity use would have increased by about 0.3 million Btu per year. For all 124 houses this would be equivalent to an increase of about 2.3 billion Btu per year.

\subsection{FORT POLK CASE STUDY}

The project selected from the Fort Worth Army Corps district office ts a family housing development at Fort Polk near Atexandria, Louisiana. The Fort Polk climate region falls into the "hot and humid" category. This housing project involved four different housing types for a totol of 350 units. A two-story townhouse type was chosen for analysis.

The Army uses a mix of prescriptive and performance efficiency criteria. Key energy-eficiency requirements are specified in the Procurement Procedure Manugl for Army Family Housing. District engineers are relied on for some requirements. Energy requirements stated in the RFP include an energy budget for each type of housing unit and specified component U-values. The mechanical engineer in the district military design branch typically prepares the site-specific requirements for heating and cooling equipment and energy features for the RFP and verifies that proposals meet the requirements.

\subsubsection{Agency Impacts}

As with the other agencies, the DOE standsads would afiect the Army procurement process at two points: RFP preparation and proposal evaluation. The time required to generate the standards is very comparable to the time devoted to selecting efmciency requirements in the Army's current process. The mechanical engineer at the Fort Worth district office indicated that nunning the COSTSAFR program to produce point system forms for inclusion in the RFP could be accomplished easily. He and the project manager agreed that a narrative description of the standards could be added to the RFP with a minimum of effort.

The mechanical engineer took 20 hours to leam to use COSTSAFR and 4 hours to produce the compliance forms. He found the requirements to be compatible with non-energy requirements of the project. He did not encounter any problems with the software or user's manual. He suggested that economlc data would need to be updated annually.

Fort Worth staft said they would probably spend no more dme evaluating proposals prepared with the DOE standards than they currently spend. Under the DOE standards, the designer would be required to complete and submit the paper point system or CAPS compliance forms, or ACP, with his or her 
proposal. They felt the forms generated by CAPS would improve the evoluation procedure and give a clear indication of compliance.

Fort Worth staff felt, however, that designers would never use the ACP because of the time and effort involved.

\subsubsection{Designer Impacts}

The designer felt the point system was ensy to understand, especially when compared with other conservation standards. He also stated that CAPS encouraged experimentation allowing different options to be examined.

The designer raised several concerns about the paper point system and CAPS. One of the building designs in this case study could not be nully evaluated because the point system does not include a combined noor type option (e.gn a building with a slab on grade, a crawl space, and a basement). The designer was concerned about maintenance of the DOE standards' databases. He noted that agency personnel will be reluctant to update the data because of unfamiliarity with the program or concern about making a mistake.

The designer felt that the COSTSAFR point total requirements for the Fort Polk redesigns were low and too easy to meet. The COSTSAFR anglysis for this project was based on an electricity price to the Army of $5.9 \mathrm{cen} L \mathrm{~s} / \mathrm{kWh}$ in the winter and $5.7 \mathrm{cents} / \mathrm{kWh}$ in the summer. These prices, which were lowrer than those available to the general public, skewed the resulting point system generated target point totals toward low efficiency requirements.

\subsubsection{Redesign of the Army's Fort Polk Units to DOE Standards}

The original two-story townhouse design achieved 66.9 points in the point system for the DOE standards, exceeding the minimum 55 points required by the standards. Two redesigns were performed. The first decreased the energy eficiency level by selectling ECMs that resulted in a point total of 57 (near the minimum requirement of 55) and reduced the capital cost of the project to the maximum extent possible. The designer chose to elimingte the 8-mil infiltration wrap on all exterior walls, dropping infiltration levels from "tight" to "average;" substitute R-11 unfaced batt ceiling insulation for R-38; substitute single-pane aluminum frame windows for the thermal-break double pane aluminum frame windows; and delete the 1 -in. insulation on the exterfor walls. This redesign decreased the estimated capital cost by $\$ 1,940$ per unit; however, Hfe-cycle energy costs increased $\$ 1,360 /$ unit. Thus, the net effect was a reduction of $\$ 580$ in total life-cycle cost per unit. With 308 units of this type at Fort Polk, the estimated overall savings from this redesign equal \$178,640. Annual electrical energy consumption per unit would have increased about 5.8 million Btu per year.

The second redesign of the two-story townhouse aimed to decrease the capital cost while maintaining the original design's 66.9 point total. By using CAPS, the designer found ways to eliminate expensive options and add inexpensive options that kept the total points the same. For essentially the same energy perfornance, the designer was able to reduce estimated capital costs by $\$ 1,119 /$ unit. For 308 units the total estimated savings from this redesign are \$\$386,232.

While the project's original two-story townhouse design was considerably more energy-efficient than required by the DOE standards, the original single-story townhouse design just barely complied with the standards. This shows that the DOE standards account for specific conditions, such as building configurations and fuel prices, in setting their requirements; whereas the existing Army requirements aim at achieving energy-efficiency based on very general conditions. From the agency perspective, the 
specincity inherent in the DOE standards could lead to housing designs that are more cost-effective as well as energy efficient.

\subsection{FORT IRWIN CASE STUDY}

A second Army case study was sejected for the demonstration. This project, selected through the Army's Sacramento district ofifice, is a 270-unit family housing project located at Fort Irwin near Barstow, Callornla, which falls into the "hot" climate category. Four house types were built in the Fort Irwin project but the redesign focuses on one type, the single-story ranch house, of which there were 26 units.

The energy requirements stated in the RFP for the Fort Irwin housing project followed the procurement procedure manual and requirements discussed in the Fort Polk case study.

\subsubsection{Agency Impacts}

The Army project manager felt the time required to use the standards during RFP preparation would be very comparable to the time required by the current process; thus the standards would impose no additional burden on district ofifice staff.

The project manager found the user's manual clear, understandable, and well written though he suggested that the Disk Operating System (DOS) should be discussed in more detail. The Sacramento ofice had concerns about duplicating the CAPS diskette for distribution to interested bidders (up to 200 requests for bid packages may be received).

The Sacramento office staff felt that the conservation levels required in the DOE standards were low (due primarlly to the low fuel prices, noted below, that the Army was able to obtain). They said that contractors in Californla have to meet tighter state requirements. They suggested that market fuel prices should be used rather than the low fuel prices paid by the military bases to beef up conservation levels.

During proposal evaluation, it appeared that the standards would not increase the workload any significant amount. The Sacramento ofiicials believed the specificity of the point system will help make evaluations easier and the point system forms for the standards might provide a convenient way to establish extra credit for designs that did better than the minimum eficiency requirements.

\subsubsection{Designer Impacts}

The designer spent 30 minutes learning how to complete the paper point system and 15 minutes learning the CAPS software. He liked the simplicity of both the paper format and the CAPS program and could not think of any major drawbacks. He liked the feedback provided when making ECM selections using CAPS and liked seeing the impact of these selections on the point total. The designer did feel that some of the equations in the paper point system forms were unclear. The designer felt the point system could be useful as a design tool and suggested that it provide cost estimates with each ECM.

However, the designer felt the DOE standards would elimingte energy conservation as a competitive factor because of the low minimum requirements generated in this case. The software analysis for this project was hased on a liquid petroleum gas (LPG) price of 39 cents/gallon, a natural gas price of 42.9 cents/therm, and an electricity price of 3.1 cents/kWh. LPG was used as the space heating and water heating fuel. All three fuel prices were well below typical market prices, causing the DOE standards to generate lower energy efliciency requirements. 


\subsubsection{Redesign of the Army's Fort Irwin Units to DOE Standards}

The redesign focused on the single-story ranch house. Ceiling, wall, and window measures were reduced and slab insulation was added in a hypothetical redesign. The designer chose to not drop the conservation measures all the way to the minimum levels set by the DOE standards.

Whth this redesign, the life-cycle cost of energy would decrease by approximately $\$ 52$ per unit. The capital cost also would decrease by around $\$ 2,700$ per unit, for a total life-cycle cost decrease of about $\$ 2,752$ per unit. The decrease in annual energy consumption would have been about 1.3 million Btu per house or about 34 million Btu for the 26 ranch houses in the project. The change in energy consumption for each unit would be comprised of a 1.5 million Btu annual reduction in LPG use and a 0.3 million Btu annual increase in electricity use.

After the redesign and analysis was completed, it was discovered that the agency had used incorrect fuel prices in the COSTSAFR runs. ${ }^{(a)}$ The prices were too low for both LPG and electricity. The correct LPG price should have been 49 cents/gallon and the electricity price should have been 8.5 cents/kWh. PNL ran COSTSAFR using the correct fuel prices and found that the minimum requirements of the standards would have become more energy efficient. The optimum conservation measure levels would have been the following: R-19 ceiling insulation, R-11 wall insulation, two feet of R-5 slab insulation, double-paned windows with aluminum frames, a furnace AFUE of 0.75 , and an air conditioner efficiency of an 8.0 SEER.

Compared with the requirements based on the erroneous fuel prices, the estlmated space heating and cooling energy consumption would have decreased $10 \%$. Compared with the redesign generated by the designer, the estimated heating and cooling energy consumption would have decreased by over seven percent, and compared with the actual design of the buildings it would have decreased five percent. In all comparisons, the requirements of the standards would have increased energy emciency if the correct fuel prices had been used.

\subsection{NAVY CASE STUDY}

The Navy project selected for this demonstration was developed under the auspices of the Westem Division of the Naval Facilities Engineering Command in San Brono, California. The project consists of 300 townhouse units located at the Alameda Naval Air Station in Alameda, Californis, and fits in the "mild" climate category.

The Navy's housing procurement procedure begins with a base's request for additional housing. Once Headquarters approves the request, a site is selected, a Site Engineering Investigation and environmental assessment are completed, and the RFP process begins.

Energy efriciency comprises about $3 \%$ of the total score assigned to proposals. In 1989, the Navy adopted two options for meeting energy-efnciency requirements. Field ofices may use a set of minimum prescriptuve requirements combined with an energy budget developed by the Navy in 1989, or they can use COSTSAFR.

(a) When the error was discovered, the person who had performed the agency runs had taken another position and it was not possible to reach him to obtain further information on his choice of fuel prices. 
The Navy was the first government agency outside of DOE to have firsthand experience with the DOE standards. However, the Navy's attempts to apply the DOE standards began in the mid-1980s-several years before this demonstration of the standards--and without documentation, training or assistance from DOE. The Navy's initial experlence with the standards was not successful and has made the Navy reluctant to use the standards again.

\section{4,1 Agency Impacts}

During the initial procurement stage, the DOE standards would probably increase the workload of division field oflice staft by several person-hours if the DOE standards were used rather than the Navy's minimum reguirements/energy budget approach.

Navy stafi were concerned about the bulkiness of point system paper reporting forms. Use of the CAPS software greatly reduces the complexdty and bulk of the paper point system. Unfortunately, CAPS was not available when the Navy first applied COSTSAFR.

Nevy staff stated that they were concerned about how many point systems must be generated for each procurement. To permit the fexibility currently allowed by the Navy, point systems mould have to be provided to designers for all possible housing types; this would increase the amount of paperwork included in the RFPs.

The Navy also noted COSTSAFR's limitations in simulating two or more housing types within one structure; and in keeping up with new energy technologies and data.

During the evaluation process, it appeared that the DOE standards would slightly reduce the labor required at the field office level. If proposers used CAPS to show compliance, Navy evalnators would have needed only to check point totals to confrm compliance. Innovative designs, however, would require use of the ACP and additional work

The Navy liked the nexibility that the DOE standards gave contractors to make tradeofis based on their actual costs while ensurng energy emiency. The Navy's prescriptive requirements, and the Btu energy budget, do not take into account life-cycle cost effects. Thus, the DOE standards provide a more thorough analysis (as required by law) than the other approaches. However the Navy raised some specific concerns about the standards because California building codes and the Navy minimum requirements often exceed the minimum insulation levels required by the standards.

After the selection of a proposal, COSTSAFR and CAPS may save as much as 7 or 8 hours of field office labor. Navy staff now require about 8 person-hours to recalculate the energy budget and ensure that minimum requirements are met. CAPS could provide this information in a one-page printout.

\subsection{Designer Impacts}

The costs to the designer of using the DOE standards' point system are likely to be minimal. Compared to the Navy minimum requirements approach, the DOE standards may increase the labor designers must devote to preparing their proposals. However, the Navy also requires that designers calculate an energy budget in Btu per square foot. The DOE standards' CAPS program fulnils this function. Overall, the standards allow the designer greater fexdbility than is permitted with the Navy's minimum requirements.

The designer also felt that the DOE standards produced low minimum requirements. In this case study, the agency fuel prices were not below typical market prices. The DOE standards analysls for this project was based on a natural gas price of 57 cents/therm and an electricity price of $7.6 \mathrm{cents} / \mathrm{kWh}$. 


\subsubsection{Redesign of Navy Units to DOE Standards}

The design firm's redesign minimized first cost and slightly exceeded the DOE standard's minimum point total requirement of 34 points. Changes made under this redesign included using $R-19$ ceiling insulation in place of R-30; decreasing the foor insulation from R-19 to R-11; removing a polyethylene vapor retarder sheet for inflitration control to move from "tight" to "average" infiltration control measures; substituting single-pane, aluminum frame windows with no coatlngs for low-E double-pane, aluminum frame windows, and installing a less eficlent furnace. Some of these features would not comply with the Navy's current minimum requirements.

Compared with the original design, this redesign would decrease capital cost an estlmated \$2,386 per unit. Because the units would be less energy-efricient than the actual units, the discounted present value of life-cycle energy costs would increase about $\$ 1,122$ per unit, for an overall life-cycle cost decrease of \$1,264 per unit. The DOE standards would have decreased the estimated overall life-cycle costs for

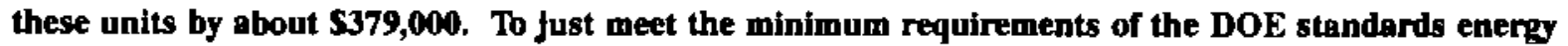
consumption would increase by about $\mathbf{1 1 . 2}$ million Btu per unit per year, or an estimated 3.36 billion Btu per year for all 300 houses. The change in energy use would all be in the form of natural gas.

This case study was unique because the fuel prices were close to typical market prices. In this case the minimum requirements of the DOE standards were still below the agency's requirements; therefore, fuel prices alone did not cause the differences. This outcome suggests that the effect of other factors included in the DOE standards should be investigated further. ${ }^{(\bullet)}$ It also illustrates that agency prescriptive requirements may not be optimal.

\subsection{PUBLIC HEALTH SERVICE CASE STUDY}

The housing project selected for this case study was the Indian Health Service (IHS) staff quarters for the Rosebud Sioux Tribe located in Rosebud, South Dakota, in the "cold" or "very cold" climate category. The Rosebud staff quarters project includes five housing types in a total of 76 units. The threebedroom ranch house ( 29 units) was selected for the redesign.

The IHS is a branch of the Public Health Service (PHS) and relies on the PHS regional Ofices of Engineering Services (OES) to perform housing procurements. The Rosebud housing project was procured through the OES in Seattle. IHS housing is built primarlly for civil servants, medical staff, and officers located in remote areas. At most, 200 units are built in a year.

Energy-efficiency requirements are introduced in the cost proposal RFP and are usually based on the professional fudgment of the OES staff rather than being prescriptive. Bidding designers may be required to prepare an "Energy Conservation Report" including descriptions of energy consumption and conservation options. They may also be asked to discuss energy consumption, fuel alternatives, mechanical and electrical systems, energy management, basic concepts for power distributlon, and lighting and special systems.

In the original Rosebud project the RFP required the deslgner to review the DOE interim standards and "establish specific standards and requirements pertinent to this project." However, the OES branch that prepared the RFP expected the designer to conduct the bulk of the analysis required under the DOE

(a) With the new discount rates incorporated in COSTSAFR Version 3.1 in 1991, however, the DOE requirements would probably have been very close to the Navy's actual requirements. 
standards, rather than having the branch perform the initial analysis as the standards intended. This suggests that proper training is necessary for government agencies involved in the procurement of housing to ensure that the DOE standards are implemented properly.

\subsubsection{Agency Impacts}

Because the IHS process to seject a deslgner does not explicitly involve energy efficiency the DOE standards do not affect the OES procurement process during proposal preparation or selection of a designer. Once a designer has been selected, however, the standards would impact the agency's subsequent contract negotiations with the designer, and the management of the design contract.

OES staff spent 10 to 20 hours learning the COSTSAFR program and four hours producing the paper point system forms for inclusion in the cost RFP.

OES staff said using COSTSAFR will require them to obtain input data (fuel costs, area cost multiplier, and price escalation figures) not required under the current procedure, but the fuel cost data could be obtained through the IHS area office where the housing project is built and default data could be used for the remaining information. ${ }^{(n)}$

OES staff felt that CAPS output data generated by the designer would provide the OES with summary information on the designer's recommended conservation messures and on the design's ability to comply with the standards. They also stated that concentrating a building design's energy-eficiency information onto one page, and presenting the information in terns of energy dollars, provides a solid reference point to quickly and accurately compare various design elternatives.

Staff at the Seattje OES stated that they would benelit from using COSTSAFR and CAPS as a design tool. Staff theorized that the DOE standards may reduce cost by allowing them to standardize designs across projects. Staff indicated that training at the OES level would be very Important and recommended a two-day seminar for all project managers and engineers who will use the software.

Staff predicted that the ACP would probably not be used in PHS projects because it's not very practical and designers have no experience with DOE-2 or other simulation models.

OES staff commented that a process should be instituted to update the standards to include new technologies and conservation measures. The OES particlpants also mentioned that the software required g working knowledge of DOS, which not all users have.

OES staff noted that the minimum conservation levels required by the standards were well within current practice. The minimum requirements were based on a relatively low electricity price of 3.5 cents/kWh and reduced the minimum requirements specified by the point system.

\subsubsection{Designer Impacts}

The designer found that the point system definitely requires less expertise and time than the current process and also stated that the point system probably allows more accurate interpretation of requirements. The designer spent three hours learning to use and applying the paper point system, and 15 minutes doing the same with CAPS.

(a) Using default values, however, would not take site-specific conditions into account in the analysis and this would partially defeat the intent of the standards. 
The designer preferred the CAPS tool to the paper point system compliance forms. She noted that it gave instant feedback on the effectiveness of proposed conservation measures and could almost be used as a design tool. She pointed out two technical timitations with CAPS: it did not allow interpolation of conservation measures, for example to insulation levels between those included in CAPS, and it did not permit saving a point system for later recall to make revisions.

\subsubsection{Redesign of Public Health Service Units to DOE Standards}

The standards required a total of 92 points for the three-bedroom house. The original design achieved 110.0 points so the designer was asked to redesign the units to reduce capital costs and just meet the requirements of the standards. The designer considered several possible options: removal of the insulation in the nooring between the ground noor and basement, removal of the air-infiltration berrier, and replacement of wood window frames with aluminum frames.

The redesign would have reduced construction costs hy about $\$ 1,200 /$ unit. For the 29 three-

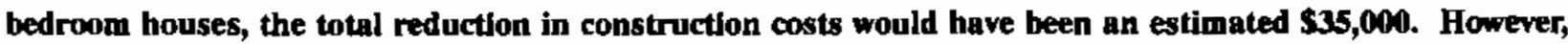
the redesign would have increased the life-cycle energy costs by about $\$ 1,462$ per unit, producing an estimated net life-cycle cost increase of about $\$ 262$ per unit. ${ }^{\left({ }^{(0)}\right.}$ Lfe-cycle energy costs for the 29 houses would have increased about an estlmated \$42,398, and overall life-cycle costs would have increased about $\$ 7,308$. The redesign would increase annual energy consumption hy an estimated 11.5 million Btu per unit, or 335 million Btu per year for all 29 houses. The change in energy use would all be in the form of electricity.

In this case study, the designer also used CAPS four times to analyze four alternative building orientations, which brought up an important issue. One of the orientations failed to comply because it had no south-facing glazing. This result may pase a problem for agencies and designers using the standards and suggests that speclal steps must be taken if orientation is to be considered.

This redesign highlights one other limitation of the standard. The actual project used a water source heat pump for space heating and cooling. The standards, however, do not contain the data necessary to analyze water source heat pumps directly, only air source heat pumps.

(a) The designer did not select all the ECMs selected by COSTSAFR as optimum for her redesign, so the life-cycle costs actually increased slightly. 


\subsection{DEMONSTRATION PROJECT FINDINGS AND DISCUSSION}

This chapter summarizes PNL's fndings on the impacts of the Interim Energy Conservation Standards tor New Federal Residential Buildings. These findings are based on the information collected during this demonstration. They document the process, energy, and cost impacts of the standards on agencies that must use the standards and designers and builders who must comply with them. They also provide information about DOEs role in implementing the standards.

\section{S.1 PRESENTATION OF FINDINGS}

The approach described in Chapter 3 was used to develop the findings. First, DOE and PNL defined a set of gasls and objectives for the standards. Second, PNL determined which comments, observations, and data points collected during the demonstration were related to each objective. Third, PNL determined how well the standards satisfied each objective from the specific comments, observations, or quantitative data relevant to the objective.

For presentation of the findings in this chapter, the objectives were grouped into specific categories. The first category involves how well the standards achieved energy savings and the use of renewable resources. The second set involves impacts of the standaris on the agencies required to apply them. The third set addresses impacts of the standards on designers and builders. The final set involves DOE's role in implementing the standards. These findings provide the basis for the recommendations presented in Chapter 6.

\subsection{IMPACTS ON ENERGY EFFICIENCY AND USE OF RENEWABLE RESOURCES}

The DOE standards' impacts on energy efriciency and use of renewable resources in federal housing were assessed based on six of the objectives discussed in Chapter 3.

\subsubsection{Achieving Maximum Practicable Improvements in Energy Eficiency}

All five federal agency housing projects included in the demonstration showed that the minimum conservation levels needed to comply with DOEs standards were less stringent than or equal to the levels acturlly used in the projects. This result was not anticipated before the demonstration project began.

Athough this result is surprising, other information is necessary for the reader to understand its significance and implications. The following sections help explain this result.

\subsubsection{Establishing the Standards' Energy-Efriciency Requirements}

The law under which DOE developed the standards called for the standards to achieve the "marimum practicable improvements" in energy efficiency. Congress also called for "federal pollcies and practices to ussure that reasonable energy conservation features" (emphasls added) were incorporated in new federal residential buildings. One of DOE's first steps in developing the standards was to determine what was meant by "maximum pructicable" energy-eficlency improvements and "reasonsble" conservation features. DOE chose to use an economic test to determine which efriciency improvements were reasonable and the maximum practicable.

Because all federal agencies are required to use life-cycle cost analysis in procurement decisions, DOE used life-cycle costing as the economic test. The life-cycle costing process and assumptions are 
specified by the Federal Energy Management Program (FEMP).(^) In a life-cycle analysis, capital costs are weighed against energy cost savngs to determine optimum efficiency levels. ${ }^{\text {(b) }}$

The DOE standards identify those optimum conservation measures that minimize the life-cycle cost, for a specific bullding and these optimum measures are used to establish an energy-efficiency target that federal housing projects must meet or exceed. The target set by the standards is in terms of energy bills (energy consumption times energy cost), rather then energy consumption alone.

When federal housing project fuel and energy price data were collected during the demonstration, it became evident that some federal agencies obtain fuel and energy at exceptionally low prices. ${ }^{\text {(c) }}$ Table 5.1 shows that the fuel prices paid by the military can be as little as one-third of the average residential prices.

The effect that energy-efficiency improvements have on utility bills depends on utility and fuel prices, as well as the amount of energy saved. Although a specinc conservation measure saves the same amount of energy regardless of energy prices, the utility bill reduction is less if energy prices are less. Because the FEMP procedure currently requires the life-cycle cost analysis to use the actual utility and energy prices paid by federal agencies, the relatively low energy prices paid by some agencies reduce the economic benefits of investing in higher efficiency levels, thus leading to relatively low energy-efficiency requirements. This is the basic reason the requirements of the DOE standards observed during the demonstration were comparatively low.

Demonstration participants expressed reactions to the low requirements such as suggestions thet the standards be based on prevailing residential market prices rather than the bulk rates paid by federal

TARLE 5.1. Actual Federal Housing Fuel Prices

\begin{tabular}{|c|c|c|c|}
\hline Federal Housing Project & $\begin{array}{l}\text { Nat. Gas } \\
\text { S/therm }\end{array}$ & $\begin{array}{l}\text { LPG } \\
\text { \$ipal. }\end{array}$ & $\begin{array}{l}\text { Electricity } \\
\text { \$2Wh }\end{array}$ \\
\hline Fort Irwin $\mathbf{C A}$ & $\mathbf{N} / \mathbf{A}$ & 0,39 & 0.031 \\
\hline Fort Polk LA & $\mathbf{N} / \mathbf{A}$ & $\mathbf{N} / \mathbf{A}$ & 0.058 \\
\hline Ellsworth SD & 0.20 & $\mathbf{N} / \mathbf{A}$ & 0.072 \\
\hline Alameda Naval Alr Station CA & 0.57 & $\mathbf{N} / \mathbf{A}$ & 0.076 \\
\hline Rosebud Stafi Housing SD & $\mathbf{N} / \mathbf{A}$ & $\mathbf{N} / \mathbf{A}$ & 0.035 \\
\hline California 1989 Average & 0.54 & 1.02 & 0.095 \\
\hline Louisiana 1989 Average & 0.57 & 0.91 & 0,074 \\
\hline South Dakota 1989 Average & 0.48 & 0.92 & 0.068 \\
\hline
\end{tabular}

(a) Erroneous fuel prices were used by the agency in its analysis. The correct prices are $\$ 0.49 / \mathrm{gal}$, for LPG and $\$ 0.085 / \mathrm{kWh}$ for electricity.

(a) Note that in 1991, FEMP lowered the real discount rate to be used in the procedure from $7 \%$ to 4.7\%. DOE's demonstration of the standards was initiated prior to the rate reduction and, therefore, all results refiect the $7 \%$ rate. If the new rate had been used instead, the minimum efficiency requirements set by the standards would have been higher than those discussed in this report. Version 3.1 of COSTSAFR incorporates the new discount rate.

(b) This basic approach is essentially the same as that used to set numerous state and regional residential conservation standards, although discount rates and input assumptions vary.

(c) The causes of the low rates are discussed later. 
agencies. One designer suggested that the federal government should take a societal perspective in the standards and include the indirect costs, or the costs of "externalities" that society bears, in the fuel prices used in the standards.

Two important questlons arise about this issue. First, why are the fuel prices paid by agencies so low? Second, why do current agency efficiency requirements typically exceed the cost-effective levels calculated based on the fuel and energy prices paid by the agencies?

Inadequate information was available during this project to determine why the prices were so low in each specific case. However, military faclitles often provide their own energy system infrastructure components, such as electricity sub-stations and transmission and distribution systems. Energy prices to military facilities can be lower than private sector residential prices becouse the utility does not have to recover these costs through rates. Although no detailed research was done during this project on the issue of the full energy costs faced by federal agencies, this one factor is probably the major renson that agencies often pay low fuel and energy prices. Local residential energy prices are likely to be good initial indicators of the full cost of energy for new federal housing because they include these costs.

The second questlon is why the agencies currently require emciency levels that exceed the costeffective levels based on agency energy prices. One explanation is that the agencies implicltly include the costs discussed above in their energy-efficiency assessments. Another may be that the agencles consider certain minimum emciency requirements (for example, dual-pane windows) to be necessary to ensure adequate comfort, construction quality, and other non-energy characteristles. A third factor may be that the agencies look to current local codes as guidelines for suitable efficiency levels. All these reasons have probably played a role in motivating the agencies' behavior.

Based on the evidence from this demonstratlon project, PNL believes that, from the perspective of direct economic impacts on federal agencies, the standards rellect the congressional directives 1) to achieve maxdmum practicable energy savings and 2) to ensure the incorporation of reasonable conservation features. Nevertheless, there is adequate evidence that higher efficiency levels are achievable, they could probebly be justlfied by taking into account the full cost of energy to federal agencies, and higher efficiency would provide societal benefits beyond those resulting from the minimum efijeiency levels required by the DOE standards.

In addition to these lssues, the fact that one agency participant used incorrect fuel prices in the demonstration of the standards raised another important issue about communicating to agencies the importance of using the proper fuel prices in their analyses. PNL worked closely with the agencies during the demonstration, but even so the wrong values were selected for the analysis in one case. The incorrect prices were so far from the proper values that the energy-eficlency requirements of the stundards were substantially different than they would have been had the correct prices been used.

\subsubsection{Indirect Effects of the Standards on Energy Eficiency}

The DOE standards have a number of features that may help improve energy efnciency in ways not taken into account by current agency approaches.

One strength of the DOE standards is that, as required by law, they set performance-based rather than prescriptlve requirements for energy efijiency. Performance standards allow the designer and builder to choose how the standards will be met, rather than forcing the designer and builder to select specific conservation measures. Prescriptive requirements may produce more energy savings but will usually exceed or fall short of the economically optimum requirement for specific housing projects. 
The DOE standards also consider all major contributors, such as envelope heat loss and equipment eficiencles, to residential energy loads in an integrated framework In some cases, the federal agencles' requirements are less comprehensive.

Federal agencies also do not have consistent requirements for including water heater emeiency in new housing. Some agencles ignore water heating entirely, while others have specific requirements. Water heating can comprise a major energy end-use so it is important to establish efficiency requirements for water heating. The DOE standerds take water heating into account and give credit to water heater efficiency improvements based on life-cycle cost, consistent with the methodology used for the building envelope.

Unlike most exdsting agency procedures, the DOE standards also provide tools, the point system paper compliance forms and CAPS, that agencles can use to make decisions about the value of different conservation options.

\subsubsection{Role of the Standards}

An important issue relating to the energy savings effects of the DOE standards is what role they can serve best for federal agencies. Rather than specifying an absolute energy-ficiency requirement, the DOE standards can be understood to set a minimum requirement for energy conservation. Therefore, their basic role is to ensure that all federal housing meets or exceeds a minimum efiriciency level. This does not prevent federal agencies from setting higher standards and, in fact, the standards have a feature that allows agencies to establish minimum eficiency requirements for any building component.

\subsubsection{Updating the Standards to Include New Eneray-Emciency Technologies}

Many participants in the demonstration project expressed concems about the maintenance of the DOE standards to ensure that new data and technologies were incorporated as they became available. While demonstration results showed that the standards covered most conventional design and construction options, comments were received about expending the options available in the COSTSAFR software to include other technologies and optjons.

For energy-eficiency measures not included in the point systems, the standards offer the option of using the alternative compllance procedure (ACP). Both agency and designer demonstration participants, however, indicated the ACP was generally not very viable within the time and resource constraints of the procurement process.

\subsubsection{Accommodating and Encouraging Use of Renewable Resources}

Accommodation of renewable resources in the point systems is limited to the inclusion of suntempered designs (which arrange windows in favorable orientations) and heavyweight construction.

The point system compliance forms include no other renewable resource technologies. The only way to obtain credit for additional renewable resource technologies is to use the $\mathrm{ACP}$, and designers indicated they were unlikely to take this approach.

There was no indication during the demonstration that the standards would accommodate new renewable resource technologies. The designers did not alter their designs to obtain credit from any new technologies. Again, the ACP is the only method of accommodating new renewable technologies without a major update of the COSTSAFR tool. 


\subsubsection{Achieving Compliance with the Standards}

The exdstence of the stendards does not necessarily mean that the efficiency levels specined by the standards wlll be met in federal housing. The agencies have been generally reluctant to use the standards for stated reasons such as the standards are more lenient than some agencles' current requirements and the belief that some of the economic data in the standards may be out of date. The disappointing early expertences the Navy had using the standards without DOEs help also undermined agency acceptance of the standards.

Although agency personnel did present such reasons for not using the standards, it was also clear during the demonstration project that there was resistance to changing existing processes. The regulatlons do allow federal agencies to use their own requirements if they meet or exceed the DOE standards. This is the approach severd agencies claimed they were following.

Unfortunately, if each agency sets its own requirements, even if they exceed those of the DOE standards, they may not be performance-based and may not reflect local climste and economic conditjons. In addition, if each agency continues to use its own procedure, the potential benefits of standardization will be lost.

Even if the agencies use the standards, the standards will not achieve thejr desired goal without adequate enforcement during construction. The DOE standards are unlikely to affect current agency compliance verification directly. If the standards are effectlve, however, in increasing agency attention to energy eficiency, then agencies might increase their verfication efforts. The compliance forms (paper point system and CAPS) could be used as starting points for creating verification check hists.

\subsubsection{Summary of Findings: Impacts on Eneray Eficiency and Use of Renewable Energy Resources}

Finding 1: The DOE standards extablish a procedure based on the economic impacts that investments in residential energy efficiency have on federal agencies and this test is used to define what efficiency requirements ane both reasonable and the maximum practicable, taking into account only the direct economic effects on fedenal agencies. This procedure meets the intent of the law with regard to energyefficiency requinements.

Finding 2: When a federal agency pays relatively bw fuel and energy prices, the minimum energy-efficiency requirements extablished by the DOE standards ane bw compared with recent fedenal agency requirements and some local standards. The agencies may fail to necognize the importance of fuel prices in the anabysis for the standards and may fail to obtain the corret prices.

Finding 3: The standards alone do not strongty promote increases in federal housing energy effuciency and, where agencies obtain bw fuel and energy prices, the minimum requirements produced by the standands would not necessarity motivate agencies to "strengthen their efforts to improve the efficiency...of energy use in Federal buildings" as proposed in the National Energy Strategy (DOE J991).

Finding 4: The standards provide tooks that can assist with the design of energy-efficient federal housing.

Finding 5: The DOE standards accommodate the mast feasible and commonly used nenewable resounce technology for federal housing sun-tempering, but do not easiby accommodate active solar technologies and acher less developed renewable resource technologies; therefore, they partially meet the intent of the law with regard to nenewable energy resources. 
Finding 6: The effectivenex of the standards has been linited by agency whwillingness to implement them and may be limited in the future by passible inadequacies in user-agency enforcement procedures.

\subsection{MMPACTS OF THE U.S. DEPARTMENT OF ENERGY STANDARDS ON FEDERAL AGENCIES}

The DOE standards' impacts on agencies were identified by examining 1) their compatibility with existing agency procurement processes, 2) their relative complexity, 3) whether they promoted a consistent approach for increasing energy efficiency across the agencies, 4) whether they would encourage the collection and feedback of information, and 5) economic impacts of the standards on the federal agency employees living in the housing.

\subsubsection{Compatibility of the Standards with Agency Processes and Consistency of Effects Across the Agencies}

The overriding issue regarding agency impacts is the general compatbility of the standards with the agencies' processes. To be compatible, the standards should be relatively easy to use and cause minimum disruptlons to existing agency procedures. If consensus exists on the impacts of the standards and a fairly uniform approach is suitable for different agencies, then less tailoring of the standards to individual ggencies will be required and more consistency will exist in the treatment of energy efficiency.

The agencies indicate that, compared with their current process, using the standards will likely decrease the amount of time and effort spent establishing energy-eficiency requirements.

The COSTSAFR software is the primary tool that agencies are required to use under the DOE standards. Except for the Novy, there was consensus that COSTSAFR was easy to Jeam and use. ${ }^{(a)}$ Typically, agency staff needed about 15 hours to learn to use COSTSAFR and produce point system forms. The COSTSAFR documentation was described as ciear and understandable, although some agency staff suggested a more detailed discussion of DOS commands should be added. (b) The agencies reported that the required COSTSAFR input data are readily available, but take a few hours to acquire. ${ }^{\text {(c) }}$ One agency staff member felt that as much COSTSAFR input information as possible should be provided to the agencies.

Some common concerns and dificulties surfaced. One was the maintainability and integrity of COSTSAFR's databases. Agency personnel had concerns about the resources required if they had to maintain the software and recommended that the databases be updated annually through a centralized procedure.

Another was how to handle building designs with an unusual mix of noor types or building types, such as single-story, two-story, and three-story units all combined in one building. Agency staff anticipate

(a) The Navy was the only agency to use COSTSAFR before the demonstration. It did so without the complete documentation, instruction, and technical help that DOE provided during the demonstration. Consequentiy, the Navy's experiences were not based on the same condlutions that applied during the demonstration.

(b) A section on DOS commands and operations has been added to the User's Manual for Version 3.1 of COSTSAFR.

(c) In at least one case, an agency demonstration participant chose to use the default values provided in COSTSAFR, rather than take the effort required to collect up-to-date input values.

Unfortunately, this approach can undermine the economic validity of the requirements generated by the standards. 
dificulties arising because COSTSAFR does not have the fexibility required to analyze these unusual designs fully.

An observation specific to the Air Force was that COSTSAFR would not allow offials to evaluate solar designs adequately. Because other agencies pay less attenton to solar optlons in their current procedures, they had fewer concerns about how the standards handled solar designs.

Other relevant observations made by agency staff follow:

- The COSTSAFR documentation does not describe the ACP methodology, thus leaving the agencies at a loss about how to apply it.

- Centralized support to the agencies would reduce the diffculties of using the standards. For example, information could be provlded on area cost multipliers, price escalation indexes, and cost data updates. (*)

The agencies indicated that including a section describing the standards and the point system in their procurement documents could be accomplished easily. However, the Navy did voice a concern about the large number of pages the point systems might add to thelr RFPs. The agencies were also concerned about whether every possible glazing distribution for houses in a project would have to be analyzed individually.

Although PHS OES personnel stated that the DOE standards could be very useful, they commented that the language in the standards' documentation was more orfented to the procurement approach used by military agencies and they would like to see more generic language used.

The agencies generally found that the paper point system was cumbersome, especially when compared to CAPS. The agencies strongly agreed that the one-page compliance form produced by CAPS will reduce the amount of time required to evaluate designs and verify compliance with the DOE standards. They also felt designers could use CAPS to get a good feeling for how different designs affect energy consumption.

Agencies were not required to test the ACP as a part of this demonstration. Based on their understanding of the ACP, most personnel expressed doubts that the current ACP could be used within the limitations of the procurement process. The agency staft were concerned that using the ACP would increase costs of applying the standards.

\subsubsection{Fedback of Information}

DOE believes that negative impacts of the standards on federal agencies can be minimized only through proper feedback of informstion on experiences and problems agencies have implementing the standards.

All the agencies included in the demonstration delegate substantial procurement responsibility to Field offices. It appeared that agencles did not have consistent ways for field ofitces to feed information back to headquarters and that most agencies handled unusual field procurement situations by seeking exceptions to standard procedures and only slowly revising general policies to resolve the problems.

(a) This need was filled partially by DOE during the demonstration through a toll-fret telephone number information service, or "hotline." 
Prior to the demonstration, there was no formal mechanism for feeding information on the standards back to DOE. During the demonstration, a houline phone number was set up and it was used by agency (and designer) start participating in the demonstration. It is still maintained by DOE.

The hotline and routine contacts with the agencies during the demonstration showed the usefulness of mechanisms for facilitating the flow of information to the agencies on the standards. The need for such information fow was clearly demonstrated as was the need for even more efiective mechanisms.

\section{5-3.3 Economic Impacts on Agencies and Low. to Moderate-Income Consumers}

The case-study nature of this analysis preciuded development of statistically representative estimated cost impacts. The most direct economic impacts would be caused by changes in housing capital and operating costs. Table 5.2 summarizes these estimated cost impacts. Each of the projects was redesigned to come as close as possible to meeting the energy-efisclency requirements of the standards, based on the direct fuel and energy prices paid by the agencies. The redesigns reduced estimated capital costs by $\$ 1,200$ to $\$ 2,700$ per housing unit. Estlmated enerzy life-cycle costs decreased by $\$ 52$ in one case and increased by up to $\mathbf{\$ 1 , 4 6 2}$ per unit in the other cases. The net effect was life-cycle cost savings to the agencies ranging from $\$ 580$ to $\$ 2,752$ per unit. ${ }^{(2)}$ Total direct economic impacts on the agencles would

TABLE 5.2. Comparison of Five Case-Study Minimum-Points Redesigns Showing Life-Cycle Costs and Savings per Unit

\begin{tabular}{|c|c|c|c|c|}
\hline $\begin{array}{l}\text { Case } \\
\text { Study } \\
\end{array}$ & $\begin{array}{l}\text { Housing } \\
\text { Type }\end{array}$ & $\begin{array}{l}\text { Redesign } \\
\text { Savings }\end{array}$ & $\begin{array}{l}\text { Life-Cycle } \\
\text { Energy Cost } \\
\text { Increase }\end{array}$ & $\begin{array}{c}\text { Overall } \\
\text { Life-Cycle } \\
\text { Cost Savings }\end{array}$ \\
\hline Alr Force & split-level & $\$ 2,100$ & $\$ 814$ & $\$ 1,286$ \\
\hline $\begin{array}{l}\text { Army, Fort } \\
\text { Polk }\end{array}$ & $\begin{array}{l}\text { two-story } \\
\text { townhouse }\end{array}$ & $\$ 1,940$ & $\$ 1,360$ & $\$ 580$ \\
\hline $\begin{array}{l}\text { Army, Fort } \\
\text { Inwin }\end{array}$ & ranch house & $\$ 2,700$ & $-552^{(\bullet)}$ & $\$ 2,752$ \\
\hline Navy & townhouse & $\$ 2,386$ & $\$ 1,122$ & $\$ 1,264$ \\
\hline DHHS & $\begin{array}{l}\text { 3-bedroom } \\
\text { house }\end{array}$ & $\$ 1,200$ & $\$ 1,462$ & $-\$ 262^{(b)}$ \\
\hline
\end{tabular}

(a) This is a cost savings, not an increase.

(b) This is a cost increase, not a savings.

(a) In one case, the estimated life-cycle cost increased by $\$ 262$ per unit because optimal selections were not made in the redesign. 
vary wth the number of units bullt in a housing project. In general, using the minimum requirements of the DOE standards as the basis for federal housing energy-efficiency levels would reduce the capltal costs of new federal housing about $\$ 2,500$ per unit and would decrease the overall life-cycle cost an amount ranging from about $\$ 500$ to $\$ 2,000$ per unit.

The occupants of housing affected by DOE's standards are federal employees. In all projects, except the PHS one, the housing expenses were covered by the federal government. Occupants of the housing procured throngh the PHS OES are primartly nurses or doctors. Therefore, they are likely to be moderate- to high-income consumers. The occupants pay their utllity bills and rent, and the rent is set by headquarters. For the specific PHS project studied, DOEs standards potentially would have increased the electricity bills by an average of about $\mathbf{\$ 1 0}$ per month. This should bave been a modest but not significant economic impact on the occupants.

\subsubsection{Summery of Findings: Agency Impacts}

Finding 7: Overall, the DOE standards should fit into federal agency procurement processes without requining agencies to make major process changes or imposing significant casts on the agencies.

Finding 8: Agency representatives are concerned about how the standards could and should be modified to address unusual situations such as atypical buildings and altemative glating orientations.

Finding 9: COSTSAFR is relatively easy to use.

Finding 10: The point systems are easy to use, although the paper point systems are lengthy, and they are effective took for evaluating dexigns.

Finding 11: The alternative compliance procedure is inadequately documented and is cumbersome to use.

Finding 12: A centralized source of information for agencies using the standards would ease implementation.

Finding 13: There are nat adequate assurances that agency procurement personnel will receive all necesvary information on the standands or that DOE will receive feedback on critical implementation issues.

Finding 14: The standards have assentially no impact on bw- to moderate-income consumens.

\subsection{IMPACTS OF THE U.S. DEPARTMENT OF ENERGY STANDARDS ON DESIGNERS AND BUILDERS}

Impacts on designers and builders were based on 1) compatibility with the design process and 2) facilitation of feedback of information on the standards. Data collection focused more on the impacts on designers than builders because designers typically have the primary responsibility for energy-eficlency design choices.

\subsubsection{Compatibility of the Standards with Designer/Builder Processes}

There was consensus among the designers that the use of the DOE standards would require a minimal effort by the designers. The standards did not appear to give an unfalr advantage to firms of a certain size or with certain capabilities. Typically, it took designers only about three hours to learn and 
apply the paper point system and less than about one hour to learn to use CAPS. There was consensus that the point system requires less time and expertise to establish compliance than typical methods currently in use.

However, several designers noted that dificulties would artse when a building design cannot be fully evaluated with the standard options offered by the point system compliance forms. The most frequently mentioned example was buildings with a combination of foundation types.

The designers uniformly preferred CAPS to the paper point system, describing CAPS as easy to use, and agreejng that it encourages experimentation and allows the results of different options to be examined immedistely. In contrest, deslgners found the paper point system non-interactive.

Because all the ortginal case study designs complied with the DOE standards, the designers noted that the minimum requirements to comply using the point system seemed outdated. One designer suggested that it would be necessary to give "bonus points" in the proposal evaluation process to encourage more efficient designs. One designer suggested that the point system "optimized selections" could provide a starting point for a builder's design, and the designer could use the point system and conservation measure costs to achieve the same total number of points for the lowest cost or to increase the number of points for the least cost. CAPS could then become an essential part of the design process, since the effect of changes on overall points is easily investlgated.

Designers generally found the documentation to be clear, easy to use, and well organized. However, it was suggested that a glossary of technical terms would be helpful along with an appendix containing diagrams that show the proper way to calculate ceiling, wall, floor, and window areas.

The designers found CAPS self-explenatory, with the on-screen prompts providing all the support that was needed.

Other designer comments included the following:

- The point systems exclude some commonly used measures such as low-now faucets and shower heads, emcient lighting, and permanent shading devices.

- CAPS and the paper point system complance forms should allow interpolation between listed values.

- Estimated life-cycle energy cost informatlon is not available "on-screen" in CAPS and this information would be informative.

The ACP is the method designers would have to use to show that energy-eficiency options not included in the point system compliance forms complied with the standards. Designers typically stated that they would consider using the ACP; however, most indicated that they did not have required computer expertise and that the usual time constraints for responding to RFPs would not permit them to do the necessary computer inalyses.

\subsubsection{Feedback of Informatlon}

The viability and success of the standards will depend in part on how well designers and builders are able to inform agencies about any problems they encounter and, conversels how effectively agencies are able to communicate informatlon to designers and huilders about the standards. The Navy's experiences prior to the demonstration provided some useful insights about this issue. The Navy experlence showed that designers will make the agencies aware of difincultles that occur. 
The demonstration showed that, with the level of assistance and information provided by DOE, the designers were able to understand and correctly use the polnt systems. The designers used the telephone hotline to obtain information and DOE provided feedback when errors were Identified in the way the designers were using the paper point system and CAPS.

\subsection{Summary of Findings: Designer and Builder Impacts}

Finding 15: Overall, the DOE standards should fu well into the design process.

Finding 16: CAPS is useful as a design tool.

Finding 17: The paper point system is adequate for verifying compliance, but is cumbersome to use and impractical as a design tool.

Finding 18: The relatively low mininum antergy-eficiency requirements of the DOE standands that accurred in the demonstration might cause designers to downplay energy efficiency, but wsing the paint system to awand bonus points could encourage efficiency improvernents.

Finding 19: The point system approach does not impose unfair burdens on any types of derigners or builders.

Finding 20: The atternative compliance procedure is unlikely to be used by aty derigners.

Finding 21: Desiguers and builders are likety to atert the agencies to any problems encountered with the standand, but asristance should be provided to designers as soon as possible.

\subsection{U.S. DEPARTMENT OF ENERGY ROLE IN IMPLEMENTING THE STANDARDS}

Several of the Indings from the demonstration involved the role that DOE can play to ensure that the standards are successfully implemented. Seven objectives discussed in Chapter 3 were used to focus information collection and analysis on issues related to DOE's mole.

\subsubsection{Provision of Support and Materials to Agencies}

At the outset of the demonstration, DOE believed that some agency training and assistance would be required and that procedures had to be in place to ensure that the necessary materials reached the procurement officials.

PNL and DOE were ovallable during the demonstration to assist and train agencies, as needed. PNL and DOE were also able to ensure that field offices received all the materials necessary to use the standards.

In general, agency personnel needed the most training on running COSTSAFR. Hands-on training seemed desirable, particularly by those unfamiliar with personal computers. Agency personnel in three projects mentioned the need for DOE assistance with applying the standards to unusual buildings, egg, buildings consisting of multiple residential unit types (such as apartments and townhouses). Other suggestions included a newsletter to discuss updates and new techniques, and somebody to demonstrate the program, explain idiosyncracies, and provide advice on how to interpret the point system. 
The Navy's experiences betore and other agencies' experiences during the demonstration showed that assistance and training provided by DOE would be essentlal for successful implementation of the standards. During the demonstration, the agencies took advantage of the hotine provlded by DOE, but not extensively, probably because the demonstration was not a real application of the standards. The level of assistance DOE provided during the demonstration would probably not be adequate once the standards are used on a widespread basis.

PNL identified another significant need during the demonstration. No single document exdsts that explains to the agencies how to implement the standards. When the agencies use the standards on a regular basis, PNL and DOE will not be able to provide the same level of guldance and assistance as during the demonstration and such a document will be essential.

\subsubsection{Provision of Support and Materials to Designers and Builders}

Participating designers' comments suggested that particular kinds of assistance could be beneficial. During the demonstration, the designers received some limited training and assistance by working with PNL. Designers used the hotline to obtain answers to questions and, as part of the data collection process, frequent contacts occurred between designers and PNL, and information about the standards was passed along to the designers. One common designer comment was that ciarifications were needed to help them understand the point systems.

Even though the minimum requirements of the standards were relatively low, it appeared that DOE could encourage cost-effectlve improvements in energy efficiency by providing certain materlals, training, and assistance to designers. For example, deslgners felt that CAPS could be very useful as a design aid if additional information was provided.

It is not known whether designers would receive all the information needed to properly use the standards during actual procurements. The agencies have ralsed some concerns about the difinculty of distributing the materlals, such as CAPS and the paper point systems, to all firms interested in a particular project. If distribution is difficult or cumbersome, implementation of the standards will suffer.

Regarding the ACP, if designers are to seriously consider Innovative designs with the standards, more information and, possibly, training in the use of the ACP will be necessary.

\subsection{Monitoring and Updating the Standards}

For successful implementation of the standards, DOE needs to monitor how the standards are used, any problems that are encountered, how well bulldings comply with the standards, and their performance. As the standards become more wddely used, it wll be important for monitoring to occur. Mechanisms to allow agency and designer feedback to DOE would facilitate such monitoring.

Several demonstration participants noted that updates of the standards should be performed on a regular basis. With on-going monitoring, DOE would be able to collect the information required to perform the necessary updates. Involvement of the agencies and possibly the designers and builders in the updating process would help ensure that the appropriate changes occurred and would increase agency acceptance of the standards. Analysis of energy use by buildings constructed to the standards would also help verify the effectiveness of the standards. 


\subsubsection{Public and Industry Conments}

The public input process is an tmportant component in designing energy standerds that balance DOE's needs with those of users, suppliers, builders, designers, and public interests. Publlc comment helps ensure that societal values are represented in the standards and that the standards are not unintentionally blased toward a particuler building style or analytic technique.

The demonstration did not gather information about the public comment and involvement process, but DOE solicited public comments in the course of the rulemaking and responded to them.

Environmental documents, such as environmental impact statements or environmental assessments, must be completed before design or construction on federal housing projects begins and these processes allow for public comment. This report to Congress on the demonstration project also represents an appraach for receiving input trom public representatives.

It is likely that the expertence and understanding of the standards gained in this demonstration wili give participating agencles a strong basls for future comments. Agencies have had the opportunity to comment in the course of the case studies described in this report. Furthermore, it is likely that the issues raised in this report, based on the evaluation of the stendards, are likely to generate further public comment.

\subsubsection{Summary of Findings:_U.S. Department of Energy's Role}

Finding 22: Bectuse much of the federal agency procurement activity occurs at the field offices, training and asristance in using the standards is needed most by the field office personnel.

Finding 23: Agency training and assistance needs fall into three categories: specific documentation improvements, materials and courses to educate users of the standants, and mechanisms to provide genteral information to users.

Finding 24: There are no assurances that current agency processes will provide the necessary standards materiats to the agency personnel who need them.

Finding 25: Specific inprovements could be made in the information developed about the standards for designers.

Finding 26: The standards provide a good starting point for DOE to work with the derign community 10 promote cost-effective improvements in fedenal residential energy efficiency.

Finding 27: Dexigners may have some problems obtaining all required point systems information from the agencies.

Finding 28: Eristing information on the ACP and designer knowledge may be inadequate for dexigness to use the procedure succexsfully.

Finding 29: There is wnlikely to be a need for builder training and assistance unless innovarive energyconserving features are incorporated in federal residential buildings.

Finding 30: Mechanisms for DOE to monilar agency use of the standards will be important for their succesfoul implementation. 
Finding 31: Updates of the standands will be required to enswe their use as conditions change.

Finding 32: DOE has met is legal requirements for obtaining public input, but succestul implementation of the standards will depend on the availability of mechanisms to continue obtaining public and industry comments. 


\subsection{RECOMMENDATIONS}

This chapter presents recommendations for steps to be taken to ensure that the DOE residential standards fulfill their goals and objectlves. Recommendations are presented in five categories. Brief discussions synthesize the findings presented in this report and draw conclusions that are the basis for the recommendations.

The recommendations are directed primarlly at DOE, but since the success of the standards depends on actions taken by other parties as well, some of the recommendations are aimed at organizatlons other than DOE. All recommended time periods start from the date DOE delivered this report to Congress.

\subsection{INCREASING THE EFFECTIVENESS OF PARTICIPATION IN THE DEVELOPMENT AND IMPLEMENTATION OF U.S. DEPARTMENT OF ENERGY STANDARDS}

The effectiveness of the interim standards and the find standards will depend on how closely involved agencles, designers, and others are in the development and implementation process. Agencies in particular need to play a significant role in helplng DOE design and revise these standards, which directly affect them. DOE, In turn, needs to work with the agencies to resolve issues identified during this demonstration.

In 1991, Executuve Order 12759 was issued requiring that agencies responsible for federal buildings "ensure that the bullding is designed and constructed to comply with the [DOE rederal] energy performance standards.... Each agency shall establish certification procedures to implement this requirement (Executive Order 1991)." As a result of the demonstration project, DOE is in a position to assist the agencies in meetlng the requirements of this executive order. Through the demonstration, DOE has identified specinc assistance that the agencies need to fully implement the standards.

Recommendation 1: As soon as passible, DOE should begin assisting the federal agencies in implementing Executive Onder 12759. DOE should start working with the fedenal agencies to resolve any impediments to immediate inplementation of the standards and to develop certificafion procedwres.

Several of the findings presented in Chapter 5 related to needs for improved communicatlons among DOE and participating agencies, designers, and others. Formal groups that bring together representatives from DOE, the agencies, designers, builders, and equipment manufacturers would provide a channel for these parties to become actively involved with the standards, to review and comment on proposed components of the standards, to exchange ideas, and to identify any problems or issues that need to be resolved.

Recommendation 2: During the next year, DOE should extablish one or more committees or task forces to involve affected fedenal agencies, designers, product suppliers, techsical experts, and intenested members of the public in all aspects of the development and implementation process. Agency field office staff should be represented on the committer. One focus of the groups should be on how agencies can encourage increased energy efficiency through their housing procurement processes.

Recommendation 3: During the next six months, DOE should estabtish a newsletter to communicute with users of the standands and other interested parties. The newsletter can be used to convey information about technical matters and interpretarions of the standards. The newsletter can also be used to alert readers to 
upcoming events and meetings. In addition to the newsletter, DOE should extablish a formal listing of interpnetations for convenient reference.

Recommendation 4: Within six months, DOE should establish a system for distributing information on the standards to field offices, designers, and others who need to receive it. A method for tracking the flow of information should be instituted.

One of the clearest findings of the demonstration was the field offices' need for technical training and information. Designers also showed an interest in improving their understanding of the point system and the standards overall, although energy efficiency is not usually a primary concern in engineering and designing buildings. DOE believes that education must be coupled with future energy-eficiency standards, and today's architectural and engineering students need to understand the significance of energy efinciency in overgll building design.

Recommendation 5: Within one yeur, DOE should develop training materials and courses to educate agency personnel and dexigners in using the standards and general energy-eficient design principles. Training courses should be supplemented with materials such as video capes and computerized tutorials to be distributed to the various users. Cousse participants could be issued certificates to verify their training in the standards and energy efficient design practices.

Recommendation 6: Within 18 months, DOE should develop an energy-efficiency training program for use in architectural, engineering, and energy-planning academic programs. The materials developed for the standards should be used as the starting point for progrant materials. Within the next three years, DOE should work with selected nepresentativer of educational institutions to dexign and implement the prognam.

\subsection{IMPROVING PROCEDURES AND PROCESSES}

During the demonstration, changes were identified that could improve the procedures and processes used in the standards. The demonstration revealed that the most important procedural issue was how to determine the appropriate fuel and energy prices to use in the standards. Several other process or procedural changes deserving DOE's immediate attention were also identifed.

Recommendation 7: As soon as pasxible, DOE should begin joint naseanch with federal agencies to examine the effects of energy and fuel prices on optimum energy-efficiency bevels. DOE should investigate the sensitivity of optimum efficiency devels to fuel and energy prices. DOE should work with federal agencies to estimate their full cost of energy and fwel Until such research is completed, agencies should use typical, local residential customer fuel and energy prices when applying the DOE residential standands.

Recommendation 8: Within the next year, DOE should conduct a study to determine the external casts associated with the different fuel and energy types used in federal housing. DOE should conduct a joint study with the agencies to desemine whether such extemal casts should be included when they apply the standards.

Several types of additional infornation were identified that are needed by agencies in the near-term to successfully implement the standards. 
Recomnendation 9: Within six months, DOE should develop a brief document that describes all the steps that agencies need to follow to implemest the standards. The document should refer agency staff to existing documentation for the standards and should be designed to maximize the asse of using the standands. The document should also stress the importance of using the correct fuel prices in the standands.

Recommendation 10: DOE should work with the federal agencies to extablish a centualized source of inpul data for agencies using the nesidential standands and such a data source should be instituted within one year.

Recommendation 11: Within the next year, DOE should conduct an anatysis of the cast-effectiveness of differest energy-eficiency requirements for mined building types and buildings with diffenent orientations. DOE should then provide the results to federal agencies with guidance on how 10 apply the standards to there situations.

Several Andings showed that both agencies and designers believed that an updating process for the standards should be implemented.

Recommendation 12: DOE should begin developing a policy and procedure for updating che standands on a scheduled basis and should extablish policies and procedures for making critical updater as they are needed.

\subsection{REVISING INTERIM STANDARDS AND DEVELOPING FINAL STANDARDS}

DOE will soon begin the process of developing the final standards, but until the final standards are available, DOE will need to revise the interim standards as needed and keep the interim standards up-todate. Because resources are limited and not all changes can be made immediately, it will be important to prioritlze desirable changes to the interim standards and other activities related to the final standards.

Recommendation 13: During the net sir months, DOE should review the findings from the demonstration and, if necassary, work with fedenal agencies and dexigners to identify significant inprovements that can be made to simplify the standards and increase their fexibility. Within the nert year, DOE should develop and begin implementing a plan to make changes to the standands that simultaneousty meet boch types of needs.

Recommendation 14: During the nat six month, DOE should work with agencies and dexigners to prioritize the dexirable modifications to the COSTSAFR software that were identified during the demonstration and identify additional modifications. The modifications should focus on making the software more understandable and increasing its ability to incorporate energy conservation measures not already included. DOE should then develop a work plan for making the necessary software modifications. Within one year, DOE should begin mating the sofware changer.

Recommendation 15: During the natr six months, DOE should identify ways that CAPS can be improved as a design aid. DOE should find ways to make the paper point system shorter and easier to use. DOE also should work with the agencies and designers to develop a more understandable way to quartify the effect ohat conservation measures have on energy savings in the compliance lools.

Recommendation 16: Within six months, DOE should initiate a research project to develop an accurate, cansistent, Rexible, and equitable alternative compliance procedure for innovative designs. DOE showld review procedures developed by ather organizations and work with the task forces and committees atablished 
in Recommendation 2 to define and develop a methodology that allows innovative, energy-eficient designs to be anatyzed without undue effort and provides adequate safeguands against misuse.

In 1991, DOE is issuing private-sector voluntary residential standards tor public comment. These private-sector standards and the interim rederal standards use totally separate but similar software tools. These two standards will be implemented by different user groups, but are alike in many ways. In addition to these two standards, DOE and the Department of Housing and Urben Development (HUD) are discussing a major update of the HUD Minimum Property Standards. These three standards require very similar information, dath, and techniques. Integrating the development activities for the final residential standards and these two other stendards could reduce duplication and overall resource requirements.

Recommendation I7: In the interest of cast savings and consistency DOE should combine the development activities for all three residential standards into an integrated rerearch program. During the next three months, DOE should develop a plan for integrating the reveanch and development nequired for these three stardarts. An approach for developing common software took should be defined. The steps DOE takes to respond to Recommendations 13 through 16 should be conducted in a way that will maximize the sharing of information, revearch, and fundings among the projects to develop the three standards.

\subsection{ACCOMMODATING RENEWABLE RESOURCES AND NEW ENERGY-EFFICIENT TECHNOLOGIES}

To meet the legislative directives underlying the standards, several steps can be taken to increase the use of renewable resources and new energy-eficient technologies in federal residential buildings.

Recommendation 18; Within two years DOE should develop and conduct a competition for innovative energy efficient designs in federal housing. The competition should include the participation of one or more federal agencies.

Recommendation 19: DOE should continue cument reseanch that would provide the information and methodologies needed to incorporate solat domestic water heating in residential building standards. DOE should neview existing codes governing the use of solat domestic water heating systems and work with federal agencies, designers, industry representatives, and others to sebact appropriate codes to govern their inclusion in DOE's building standards.

Recommendation 20: Within the next year, DOE should perform an evoluation of relatively imenpensive passive solar techniques such as solar shade seneens and other external shading devices to determine their applicability for inclusion in the standards. In addition, DOE should conduct the research needed to determine the applicability of including more sophisticated and capital-intensive passive solar technologies and design strategies into the COSTSAFR program, or impnove the ACP to accommodale passive solar desigus more easily.

Recommendation 21: Within two years, DOE should perform the reseanch needed to assers the casteffectiveness and applicability of grid-connected photowoltaic systems in federal housing projects buith under the standards.

Recommendation 22: During the nea two years, DOE should develop a mechanism to allow daxigners and developers to propose the ure of wind and geothernal technologies in geographic areas where their use is likety to be cost-effective. 
Recommendation 23: During the next year DOE should develop a methodology for mapidty screening new technologies to determine their acceprability. A standardized methodology for quickly including new conservation measures in the standards, either through the ACP or point systems, should be atrablished by DOE.

\subsection{MONITORING IMPLEMENTATION AND IMPACTS OF THE STANDARDS}

During the demonstration, DOE worked very closely with agencies and designers to determine how the standards would be implemented and what their impacts would be. The exchange of information during the demonstration Jed to rapid modifications of the tools used in the standards (e.g., an energy budget was added to CAPS) as demonstration participants identifed desirable changes. As more agencies begin to implement the standards, similar data collection and information exchanges should be continued so that DOE is able to monitor the effectiveness of the standards and make necessary adjustments.

Recommendation 24: As individual agencies begin implementing the standards, DOE should develop the necessary working relationships and protocols for collecting consisfent, informative details about user experiencer. DOE should wilize the methodologies developed during the demonstration as a starting point. In cooperation with the agencies, DOE should then collect and anabze the necessary information as the basis for potential modifications to the interim standands, development of the final standards, training approaches, etc.

Recommendation 25: During the mat year, DOE should use the communication, training and coordination mechanisms propased in several ather recommendations to develop a cooperative program for enswing that builders are able to meet the requirements of the standands and that intended measures and equipment are being property installed. DOE should also work with the agencies to develop an approach for monitoring and exaluating the energy consumption of federal housing so that the effectiveness of the standards can be verified and the agencies can demonstrate they are meeting their energy savings targets.

\subsection{CONCLUSIONS}

The interim standards demonstration project has been completed and this report documents the steps in the demonstration, the findings, and PNL's recommendatjons. As Congress intended, the demonstration provided crucial information DOE needs for the development of the final standards.

The methodologies and tools that DOE developed for the interim standards were generally well received by agency personnel and designers alike. It was clear, however, that the agencles elther had resisted implementing the standards or were uninformed about them. The demonstration allowed DOE to identify impediments to more extensive agency implementation of the standards. It also revealed the need for DOE to take steps to integrate the agencies, designers, and others more into the standards development process so that their needs are better met by the standards.

The finding that was the most unexpected and had the largest impact was that the low direct fuel and energy prices paid by some agencies slgnificantly reduced the energy-eficiency requirements of the standards. Although the methodology employed by the DOE standards was consistent with the leglslative directives, the low prices that some agencies paid energy suppliers resulted in low efficiency requirements that were difficult to reconcile with other policies to increase energy efficiency. This report suggests that the fuel and energy costs used by the agencies when applying the DOE standards should reflect actual market prices, not the reduced prices some agencies pay. 
The major overall step that should be taken now is to develop a coordinated, cooperative efiort among DOE and the afiected agencles as the agencies implement the interim standards and DOE develops the final federal residentlal standards. This report presents several recommendations aimed at facllitating such a coordingted, cooperative effort to ensure that maximum practicable energy savings are achieved in new federal residential buildings in the coming years. 


\subsection{REFERENCES}

Baechler, M. C., A. D. Lee, and R. G. Lucas. 1991. CAPS Quick Refenence Guide: Version 1.1. PNL-7741, Pacific Northwest Laboratory, Richland, Washington.

Lee, A. D., M. C. Baechler, F. V. Di Massa, R. G. Lucas, and D. L. Shankle. 1991. Demonstration of the DOE Interim Energy Conservation Standards for New Federal Residential Buildings. PNL-7956, Pacific Northwest Laboratory, Richland, Washington.

Stecher, B. M. and W. A. Davis. 1987. How to Focus an Evaluation. SAGE Publications, Newbury Park, California.

U.S. Department of Energy (DOE). 1988a. COSTSAFR 3.0 - User's Manual (Conservation Optimization Standard for Savings in Federal Residences) in Support of Propased Modfications to Interim Energy Conservation Standards for New Federal Residential Buildings, DOE/CE-1222, Vol. 1, Washington, D.C.

U.S. Department of Energy (DOE). 1988b. Supplementary Technical Support Document in Support of Propared Modifications to Interim Energy Conservation Standards for New Federal Residential Buildings, DOE/CE-0222, Vol. 2, Washington, D.C.

U.S. Department of Energy (DOE). 1988c. Technical Support Document in Support of Interim Energy Conservation Standands for New Federal Residential Buildings, DOE/CE-0223, Washington, D.C. 

No. of

Copies

\section{QFFSITE}

12 DOE/Ofice of Scientific and Technical Communication

\section{J. J. Boulin}

Office of Codes and Slandards CE-43

US. Department of Energy 1000 Independence Avenue SW Washington, DC 20585

\section{S. J. Turchen}

Ofice of Codes and Slandards CE-43

U.S. Department of Energy 1000 Independence Avenue SW Washington, DC 20585

S. Walder Office of Codes and Standards CE-43

U.S. Department of Energy 1000 Independence Avenue SW Washington, DC 20585

\section{ONSITE}

\section{DOE Richland Field Ofice}

D. R Segna

22 Pacific Northwest Lahoratory

C. J. Belcher (5)

R. E. Jarmagin

T. J. Secrest

A. D. Lee (5)

M. C. Baechler

F. V. DiMassa

R. G. Lucas

D. L. Shankle Puhlishing Coordination Technical Report Files (5) 
